\title{
Fertility and Family Policies in Central and Eastern Europe after 1990
}

\author{
Tomas Frejka, Stuart Gietel-Basten
}

\section{Contributing authors}

Liga Abolina (University of Latvia), Liili Abuladze (Estonian Interuniversity Population Research Centre), Svitlina Aksyonova (Mykhailo Ptukha Institute of Demography and Social Research, Kiev), AnĎelko Akrap (University of Zagreb), Ekaterina Antipova (Belarusian State University), Mirjana Bobic (University of Belgrade), Ivan Čipin (University of Zagreb), Liudmila Fakeyeva (Belarusian State University), lonut Foldes (Babes-Bolyai University), Aiva Jasilioniene (MPIDR), Dora Kostova (MPIDR), Irena Kotowska (Warsaw School of Economics), Boris Krimer (Mykhailo Ptukha Institute of Demography and Social Research, Kiev), Elena von der Lippe (Robert Koch Institute, Berlin), Iryna Kurylo (Mykhailo Ptukha Institute of Demography and Social Research, Kiev), Ausra Maslauskaite (Demographic Research Centre of Vytautas Magnus University, Kaunas), Julia Mikolai (University of Liverpool), Cornelia Muresan (Babes-Bolyai University), Vasic Petar (University of Belgrade), Michaela Potančoková (Vienna Institute of Demography), Tatyana Pronko (UNFPA in Belarus), Allan Puur (Estonian Interuniversity Population Research Centre), Mirjana Rasevic (Institute of Social Sciences), Anna Rybińska (University of North Carolina at Chapel Hill), Luule Sakkeus (Estonian Interuniversity Population Research Centre), Jože Sambt (University of Ljubljana), Tomáš Sobotka (Vienna Institute of Demography), Branislav Šprocha (Slovak Demographic Research Centre), Rebecca Staddon (University of Oxford), Vlada Stankuniene (Demographic Research Centre of Vytautas Magnus University, Kaunas), Anna Štastná (Research Institute for Labour and Social Affairs, Prague), Marin Strmota (University of Zagreb), Nada Stropnik (Institute for Economic Research, Slovenia), Krzysztof Tymicki (Warsaw School of Economics), Anatoly Vishnevsky (Institute of Demography, Higher School of Economics, State University, Moscow), Sergei Zakharov (Institute of Demography, Higher School of Economics, State University, Moscow), Kryštof Zeman (Vienna Institute of Demography), Peteris Zvidrins (University of Latvia) 


\title{
Fertility and Family Policies in Central and Eastern Europe after 1990
}

\begin{abstract}
This paper examines fertility and family policies in 15 Central and East European (CEE) countries to establish firstly, likely directions of cohort fertility trends for the coming decade; and secondly, to provide an overview and analysis of family policies in CEE countries, and to assess their impact on cohort fertility trends. Demographic analysis suggests that the cohort fertility decline of the 1960s cohorts is likely to continue at least among the 1970s birth cohorts; stagnation cannot be ruled out. Births that were postponed by women born in the 1970s were not being replaced in sufficient numbers for cohort fertility to increase in the foreseeable future, and shares of low parity women (childless and one child) were larger than shares of high parity women among the late 1960s cohorts than in older cohorts. Also, childbearing postponement which started in the 1990s is reflected in dramatic changes of childbearing age patterns. As period fertility rates have been increasing in the late 2000s throughout the region an impression of a fertility recovery has been created, however the findings of this project indicate that no such widespread childbearing recovery is underway.

For the first time ever an overview and analysis of CEE family policies is conceptualized in this paper. It demonstrates that fertility trends and family policies are a matter of serious concern throughout the region. The following family policy types have been identified: comprehensive family policy model; pro-natalist policies model; temporary male bread-winner model; and conventional family policies model. The majority of family policies in CEE countries suffer from a variety of shortcomings that impede them from generating enhanced family welfare and from providing conditions for cohort fertility to increase. The likely further decline of cohort fertility, or its stagnation, may entail long-term demographic as well as other societal consequences, such as continuous declines in total population numbers, changes in age structures, as well as implications for health and social security costs.
\end{abstract}

Keywords: Fertility · Family policies · Central and Eastern Europe · International comparative analysis · Family policy typology 


\section{Introduction}

The demise of state socialism throughout Central and Eastern Europe had immediate demographic repercussions. Arguably changes in childbearing during the quarter century since 1990 were among the most palpable and substantial. These fertility trends attracted a great deal of interest in the scientific literature (e.g. Billingsley 2010; Frejka et al. 2008; Kohler et al. 2002; Kotowska/Jóźwiak 2003; Macura 2000; Sobotka 2004, 2011) and the present paper provides an up-to-date, comprehensive description and analysis of these developments. This is done in conjunction with a first systematic attempt to describe and analyse family policies in CEE countries during this period. Our findings are the result of an international comparative project of 40 scholars (Appendix 1) from 15 CEE countries ${ }^{1}$ conducted under the aegis of the Department of Social Policy and Intervention, University of Oxford, UK (Basten/Frejka 2015).

The two main sections of the study - section 4 discussing fertility trends and section 5 focusing on family policies - are intrinsically linked and continuously interact. It was the substantial decline in total period fertility rates (TPFRs) during the 1990s and beyond which generated a great deal of concern among governments about possible consequences. Governments feared the fertility decline could lead to an eventual serious lack of human and financial resources to support societal development, including rising health and social security costs of an aging population. Such fears were among the reasons for expanding, formulating and implementing family and related policies. At the same time, fertility trends are central among the indicators which illustrate the success or lack of extant policies.

In section 5 the evolution of the institutional settings for developing family policies during the societal transformation of the past quarter century, the family policy measures and their effects on family life and reproductive behaviour, and the challenges of implementing family policies are described, discussed and evaluated. The experience of individual countries, which is also briefly outlined, is indispensable for understanding the generalizations and findings regarding the contemporary history of CEE family policies.

The interaction of fertility trends and family policies takes place within the context of broader social economic, political and cultural trends. Arguably important ones are briefly discussed in the next section.

1 In this paper, similarly as in other analytical demographic literature (Sobotka 2011), Central and Eastern Europe is comprised of four regions, namely "Central" Europe, "South-Eastern" Europe, the "Baltic States" and "Eastern" Europe. The basic criterion for congregating countries into these regions is geographic, while historical, linguistic, cultural, economic, political and other reasons also play a role. The 15 countries that were included in the project listed by region were: Central Europe: Croatia, the Czech Republic, Hungary, Poland, Slovakia, Slovenia; SouthEastern Europe: Bulgaria, Romania, Serbia; Baltic States: Estonia, Latvia, Lithuania; and Eastern Europe: Belarus, the Russian Federation, Ukraine. 


\section{Background}

The societal transformations from communism to capitalism taking place in CEE which started in 1989-1991 are unique in human history. These transitions entail radical, complex and extremely rapid political, social and economic changes (Ekiert) Hanson 2003). The communist types of centrally planned economies, which had never before existed in history, had to be transformed into capitalist economies at the same time as the authoritarian systems attempted conversions into democracies. Under such conditions experiences of countries have understandably been uneven and varied. Nonetheless, all CEE countries have more or less progressed in reforming their societies towards open, market-based, capitalist economies, coupled with changes of political institutions, and with notable improvements in living standards in most countries.

Economic reforms have been the most successful in the countries of Central Europe and the Baltic States while those of Eastern Europe made the least progress (EBRD 2015 and Appendix Table 1).

Central European and Baltic countries have also made the most progress in improving political conditions and developing democratic institutions (Ekiert et al. 2007 and Appendix Table 2). Significant political progress had already been achieved by 2004. In contrast, a few countries have experienced nationalistic authoritarianism that mimics democracy. This is particularly the case in Russia, where it has been labelled Putinism, and to a lesser degree in some other CEE countries (Nemtsov/ Milov 2008; Rahn 2007; Albanese 2006; Zakharov 1999).

Changes in living standards since the demise of communism are another feature reflecting the fundamental societal restructuring in CEE. In most countries living standards increased significantly by 2013 compared to 1990 (Appendix table 3, last column). With the exception of Albania, Moldova and Ukraine living standards as measured by the per capita gross domestic product based on purchasing power parity (GDP per capita based on PPP) grew by between 2.3 times (Czech Republic) to 4.0 times (Poland). In almost all CEE countries growth has been faster than in the West in the past quarter century. Despite the relatively fast growth in per capita GDP, CEE countries have not caught up with Western countries. As of 2013, average GDP per person in Central Europe and the Baltic States ranged between 21 and 30 thousand international dollars per year, however in all Western countries, except for Portugal, GDP per capita was considerably higher than that (Appendix table 3). ${ }^{2}$

The disintegration of the state socialist system had a momentous impact on basic demographic developments. By 2014 almost every CEE country experienced population decline (Table 1). In contrast, almost no country throughout the remainder of Europe lost population during the past quarter century. All Baltic States, as well as the other countries of the former Soviet Union, had an excess of deaths over

2 Data in Appendix table 3 also illustrate the extremely difficult times experienced immediately after the beginning of the transition during the 1990s, and the significant progress made in the 2000s. 
Fertility and Family Policies in Central and Eastern Europe after 1990

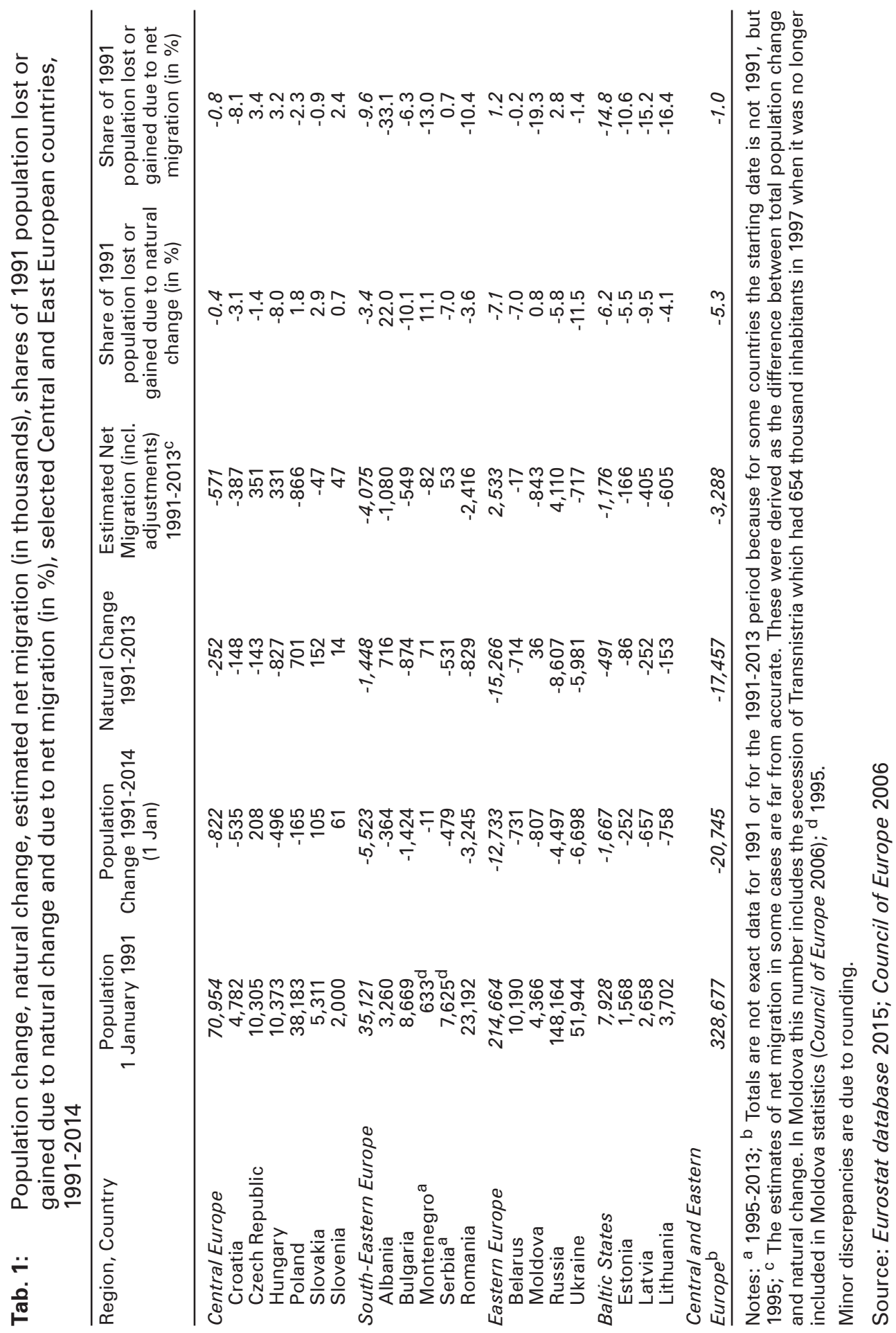


births, as did Croatia, the Czech Republic, Hungary, Bulgaria, Serbia and Romania between 1991 and 2014 (Table 1). Many countries experienced considerable emigration which in some cases was alleviated by return migration. Taking individual countries as well as the four CEE regions, natural change and net migration losses were important factors generating the declines in total population numbers. Taking the CEE region as a whole, it appears as though the main reason for the loss of population was negative natural change, the excess of deaths over births. The migration losses in the majority of countries were offset by substantial immigration to the Russian Federation ${ }^{3}$ and to a lesser degree by immigration to the Czech Republic and Hungary (Table 1). Obviously, Table 1 provides the overall picture and it has its limitations. It depicts only basic changes, and it does not inform about various serious issues, such as that proportionately many more economically active people left a number of countries, and that a share of the emigres have not left permanently.

\section{Data sources}

The Human Fertility Database (HFD 2015) provides the majority of data required for the description and analyses of the fertility trends in CEE countries in section 3 . This source is supplemented by the Eurostat database and by data provided by country co-authors from national statistical institutions' data banks. In addition some data were gleaned from the data bank of the Observatoire Démographique Européen (ODE 2012).

It is considerably more difficult to assemble data that can be used for the description and analysis of family policies, particularly for formerly socialist countries of Central and Eastern Europe. Several data banks which include family policy indicators have sprouted in recent years, but only a few of them include some CEE data. Frequently such data banks contain data only for a few CEE countries or they do not include any of these countries. An example of the former was the original version of the OECD Family Database (Adema et al. 2009) which was used by Thévenon (2011) to conduct an analysis of family policies in OECD countries; it included data for a mere four CEE countries. An example of the latter is the Comparative Family Policy Database (Gauthier 2002) which covers 22 OECD countries, but none of the CEE countries. The present version of the OECD Family Database (2016) contains data for 11 CEE countries. Appendix tables 9, 10 and 11 use these data and they are supplemented with data provided by country co-authors.

The main source of information for the description and analysis of country family policies in our study are comprehensive country reports composed by co-authors. These cover a wider range of information than merely the statistical indicators: the institutions formulating and implementing family policies, policy documents,

3 Most of this was a quasi-type of international migration consisting almost entirely of Russians that were returning to the Russian Federation from countries that had emerged as a result of the dissolution of the Soviet Union. 
an overview of the instruments, conditions for implementation, the challenges encountered in implementing family policies, and an evaluation of the impact of policy measures. The country family policy profiles in section 4.3 are an abbreviated version of country reports. ${ }^{4}$

Some tables and figures do not contain data for all 15 countries. Two reasons account for these omissions. Either the respective data were not available for all countries (e.g. Fig. 3) or we decided to include data only for selected countries as examples because including more countries would be redundant (e.g. Fig. 4).

\section{$4 \quad$ Fertility trends in Central and East European countries}

The updated overview and analysis of CEE fertility trends illustrates some of the reasons why governments are concerned and why they attempt to modify these trends. We start with a brief description of societal conditions shaping CEE fertility.

\subsection{A concise characterization of societal conditions shaping CEE fertility}

The implosion of state socialism in CEE in 1989-91 and the ensuing highly differentiated transition to capitalist political and economic conditions entailed a radical and rapid transformation of childbearing incentives and deterrents.

Three mutually reinforcing factors - the technologically lagging and labour intensive inefficient socialist economies which generated a continuous demand for labour; a pro-natalist ideology and policies; and the authoritarian political system restricting personal freedom - created conditions which were generally conducive for early and universal childbearing. These conditions included job security, lowcost housing, free education, free health care, various entitlements associated with childbirth and childrearing, as well as limited career opportunities and leisure activities. The citizens of the state socialist countries had grown accustomed to a relatively stable and predictable existence, although standard living conditions were worse than in Western countries, and there were numerous disturbing concomitants to this lifestyle, such as curtailed civil liberties and shortages of everyday and longlasting consumer goods (Frejka 2008; Sobotka 2004, 2011).

In contrast, mutually reinforcing features of the transition to contemporary capitalism - the quest for maximizing profits and productivity, the employment of advanced increasingly complex technologies, competitive labour markets, a propensity for a low priority for social obligations towards workers and society, as well

4 More detailed information will be available in country overviews. These will be published as "University of Oxford CEE family policy Country Studies" which will contain a breadth of information concerning family policies [FPs] in individual CEE countries. They will be available for download from http://www.spi.ox.ac.uk/oxpop/about-us/cee-family.html NB ceefamily.info, and will be regularly updated to reflect the latest developments in the respective country's family policies. 
as the spread of modern contraceptives - created considerably more restraining conditions for childbearing. These included job and income insecurity, an increasing pressure to acquire more education, expensive housing, lesser and declining birth and childrearing entitlements, increased uncertainty of spousal relationships as well as expanded personal freedom, the availability of a variety of career opportunities, consumption attractions and leisure activities. All of a sudden, people were exposed to societal conditions which made it more difficult to earn a living, more demanding to reconcile the family-work conflict, and under which various costs previously borne by the paternalistic state became the responsibility of individuals and families (Frejka 2008; Sobotka 2011).

All told, the balance shifted from circumstances generally encouraging early marriage and childbearing with a distinct propensity for a two-child family, to circumstances postponing union formation and childbearing as well as inhibiting family size. The propensity for two-child families started to weaken; shares of one-child families increased everywhere and even became the most prevalent in the Russian Federation and Ukraine (cf. Fig. 3).

\subsection{Fertility trends facets}

\subsubsection{Period total fertility rate trends in CEE}

Period total fertility rates in CEE countries declined precipitously during the $1990 \mathrm{~s}$ from levels centred around 2.0 in 1990 to previously unexperienced low levels mostly within the range of $1.1-1.4$ births per woman around the year 2000 (Fig. 1). This PTFR decline was similar to what had happened earlier elsewhere in Europe. It was preceded by the PTFR declines during the late 1960s and the 1970s in Northern and Western Europe, and in the German-speaking countries; and in Southern Europe where the pronounced period fertility decline occurred in the 1980s (Appendix Fig. 1).

While the period fertility decline was a common occurrence in CEE during the 1990s, there was a great deal of variation between countries, most notably in SouthEastern Europe (Fig 1, panel C). As supported by the evidence presented below, the period fertility decline of the 1990s was engendered by the postponement of childbearing into higher ages (Sections 4.2.2 to 4.2.4) combined with a continued decline in cohort total fertility rates (Section 4.2 .5 and 4.2.6).

The 2000s were marked by a recovery of PTFRs which was in part shaped by a considerable slow-down in childbearing postponement (Section 4.2.7). With the exception of a few countries, especially the Russian Federation, Ukraine and Lithuania, the recovery stalled in the 2010s. Practically everywhere in CEE the period fertility recovery of the 2000s was incomplete, i.e. the PTFRs in the 2010 s were significantly below the levels of around 1990. The stalling of the PTFRs around 2010 was most likely also caused by the economic recession in the late 2000s (Sobotka et al. 2011: 287-290). It was predominantly the childbearing of young women that was affected by the recession. 
Fig. 1: Period total fertility rates, Central \& East European region, Central, South-Eastern, Eastern Europe and Baltic States, country populations within regions, 1970-2014
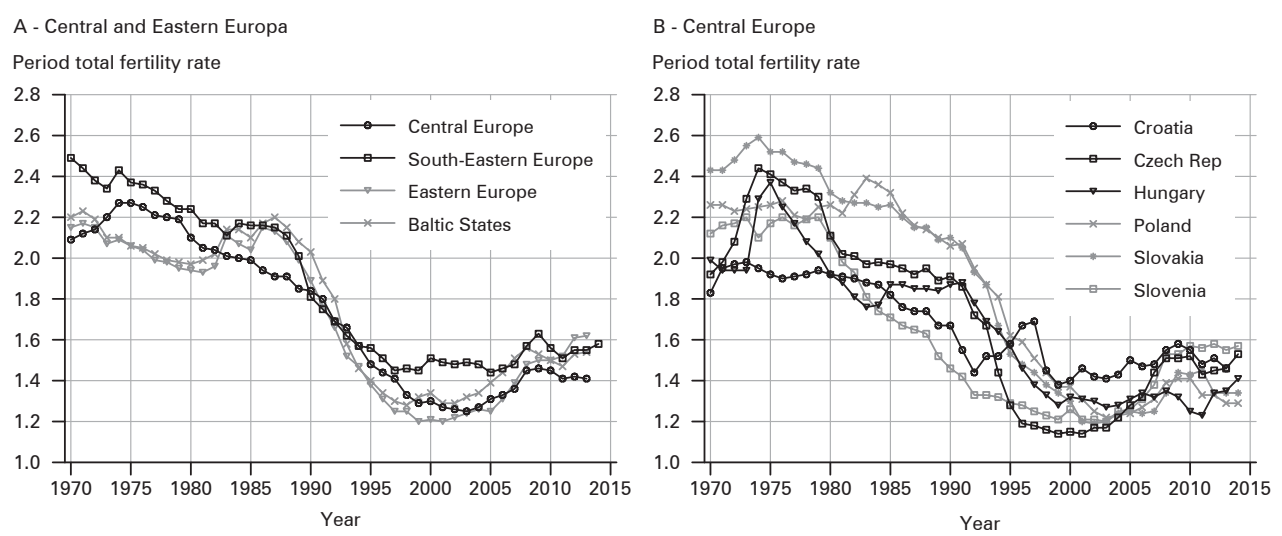

C - South-Eastern Europe

D - Eastern Europe

Period total fertility rate

Period total fertility rate
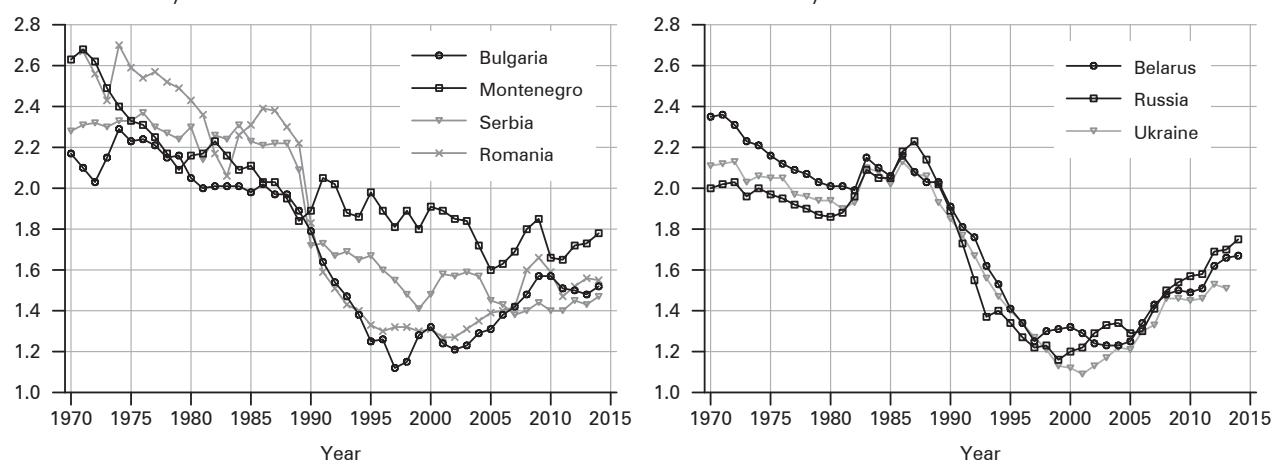

E - Baltic States

Period total fertility rate

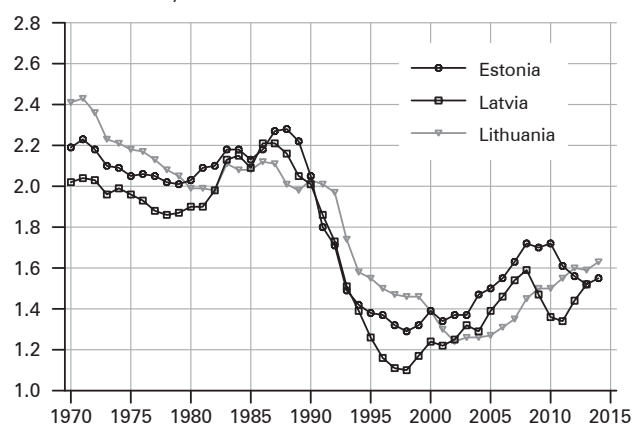

Year

Source: Human Fertility Database 2014, Eurostat 2014, Warsaw School of Economics 2015 


\subsubsection{Period mean age of women at first birth ${ }^{5}$}

Women tended to have their first birth quite early during the communist era, on average between 22 and 24 years of age. With the beginning of the transition in the early 1990s women started to postpone childbearing and the mean age of women at first birth (MAFB) started to rise and did so throughout the remainder of the 1990s and the 2000s (Appendix Fig. 2). The increase in the MAFB was most pronounced in Central Europe but slow in Eastern Europe. For instance, in the Czech Republic the MAFB grew from age 22.5 in 1990 to 27.6 in 2010; in the Russian Federation the MAFB increased from 22.7 only to 24.8 during the same period. The growth in the MAFB was putting downward pressure on the period TFR trend not only during the1990s but also during the recovery of the PTFR in the 2000s. In most countries the MAFB rate of growth slackened in the early 2010s (Appendix Fig. 2).

\subsubsection{Period fertility rates of young and older women}

The analysis of period fertility rates of young and older women presents an illuminating way to follow the progress of childbearing postponement and recuperation. At the same time, this analysis demonstrates the impact of childbearing trends of young and older women on trends of the period total fertility rate.

In Bulgaria, for instance, during the 1970s and especially during the 1980s the trends in the period age-specific fertility rates of young and of older women were essentially flat which resulted in a reasonably steady PTFR trend of around 2.0 births per woman (Appendix Fig. 3, panel B). A decline in the period age-specific fertility rate of women aged 15-26 (PASFR 15-26) during the 1990s illustrated that numbers of births of these women were decreasing. The assumption that at least some of these births were being postponed is justified. Specifically, the PASFR 15-26 declined from 1.5 births per woman in 1988 to 0.8 in 1997. This was reflected in the decline of the PTFR from 2.0 to 1.1 births per woman as also a minor decline in the childbearing trend of older women occurred during those years. Some of the births that were presumably postponed during the 1990s were subsequently borne by the same women when they were older during the 2000s. The PASFR 27-49 increased from 0.3 births per woman in 1998 to 0.7 in 2009. This was reflected in a rise of the PTFR from 1.1 births per woman in 1997 to 1.6 in 2009. Variations of these trends of the period age-specific fertility rates of young (15-26) and of older (27-49) women were occurring in all the CEE countries as illustrated by the additional examples of the Czech Republic, the Russian Federation and Lithuania in Appendix Figure 3.

Declines of the PASFRs $15-26$ in the mid- to late 2000s and early 2010s in most countries are proof that childbearing postponement was continuing, with the exception of Bulgaria and Eastern Europe (Appendix Table 4). In the latter countries, however, the potential for further childbearing postponement is large, because the

5 It might be preferable to use cohort mean ages of women at first birth for this analysis, but long enough series for CEE are not yet available. 
shares of the PASFRs $15-26$ around 2010 were high, i.e. young women were still bearing about half of all births.

\subsubsection{Cohort age patterns of childbearing}

Changes in cohort age patterns of fertility demonstrate the rapid pace of childbearing postponement into older ages that occurred during the main years of the societal transformations in CEE. In the Czech Republic, for instance, there was a sharp decline of childbearing of women in their early to mid-twenties from the 1965 to the 1970 birth cohort. The next phase was a collapse of the early fertility pattern peaking at age 20 in the 1970 birth cohort into a later childbearing pattern of the 1975 cohort with a peak at age 29. Birth postponement did not stop at that point but continued in subsequent cohorts born in the mid to late 1970s (Appendix Fig. 4, panel A). The childbearing data for women in their twenties of the 1980 cohorts indicate that the new regime of late childbearing was stabilizing.

Such a rapid pace of conversion from an early to a late fertility pattern was typical for all CEE populations. The majority of births of the cohorts born during the late 1960s that started their childbearing during the early to mid-1980s was concentrated in their teens and twenties, whereas the women who started childbearing in the 1990s were having most of their children later (Appendix Fig. 4).

The rapid pace of change in CEE cohort age patterns of fertility stands out in comparison to what had occurred in Western countries. Typically the conversion from an early to a late childbearing pattern started with cohorts born in the late 1940s and early 1950s as, for instance, in the Netherlands (Appendix Fig. 4, panel E). The peak of the age fertility pattern in the 1945 cohort was age 24 . From there on, changes in the age pattern of fertility occurred gradually with the peak age in the 1965 cohort ranging between 29-31 years. Among the next 20 cohorts, i.e. for women born between 1965 and 1985, the cohort age patterns of fertility in the Netherlands remained virtually unchanged (not shown). In Austria changes in fertility age patterns were even more gradual and continued among the cohorts born in the 1970s and 1980s (Appendix Fig. 4, panel F). In western countries changes from one cohort to the next were relatively orderly and smooth. In contrast, changes in childbearing age patterns in CEE during the societal transformations of the 1990s and 2000s were dramatic and tumultuous (Appendix Fig. 4).

\subsubsection{Cohort total fertility trends}

At the same time as the radical changes in the timing of childbearing were taking place, the quantum of fertility as measured by cohort total fertility rates (CTFRs) started to decline. This was apparently also triggered by the societal transformations in CEE around 1990. CTFR levels among the birth cohorts of the late 1940s and the 1950s had been quite stable, close to the replacement level (Fig. 2). A turning point occurred among women born around 1960. Without exception the CTFRs at age 40 fell among the 1960s cohorts throughout CEE (Fig. 2 and Table 2). 
Fig. 2: Cohort total fertility rates at age 40, Central \& East European region, Central, South-Eastern, Eastern Europe and Baltic States, country populations within regions, birth cohorts 1935-1975
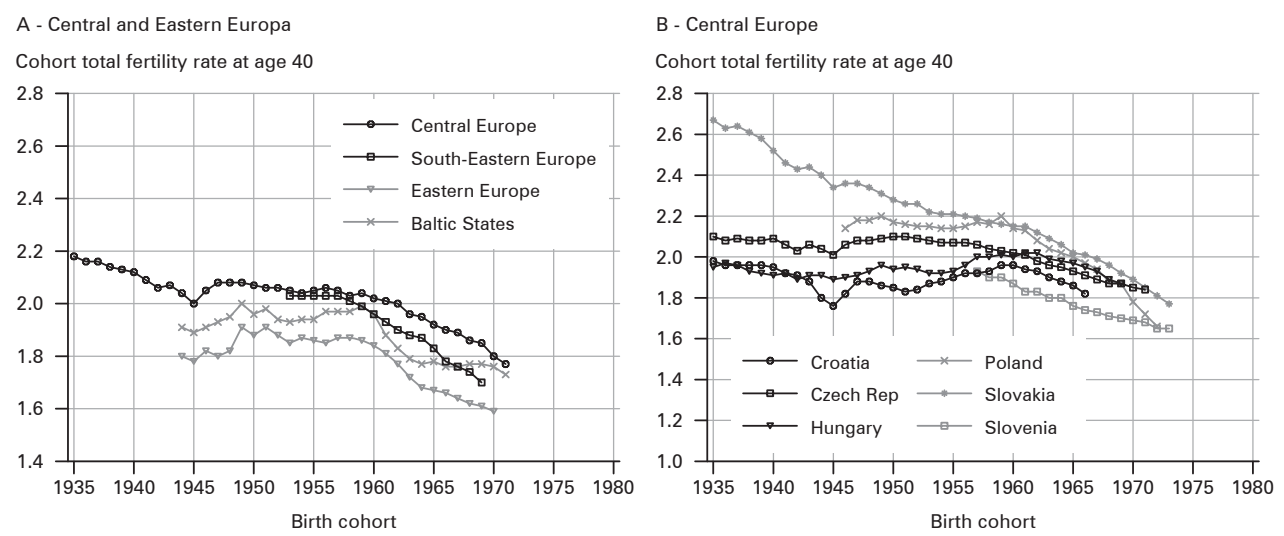

C - South-Eastern Europe

D - Eastern Europe

Cohort total fertility rate at age 40

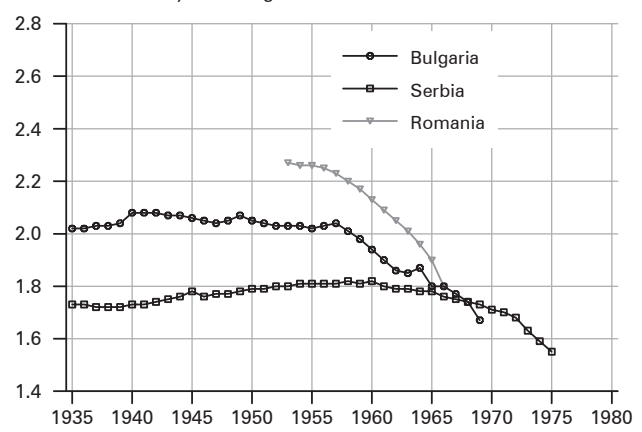

Cohort total fertility rate at age 40

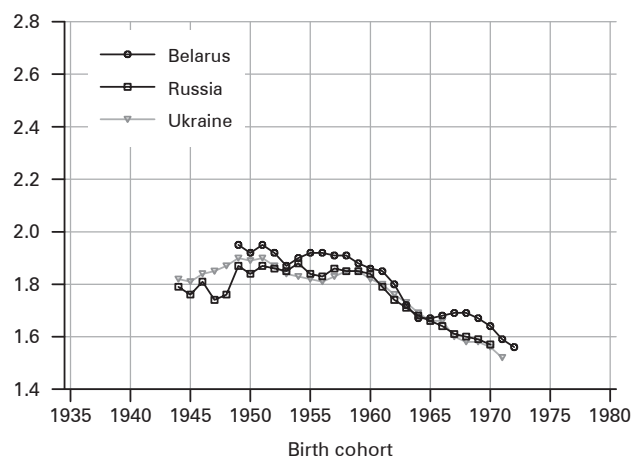

Birth cohort

$$
\text { Birth cohort }
$$

E - Baltic States

Cohort total fertility rate at age 40

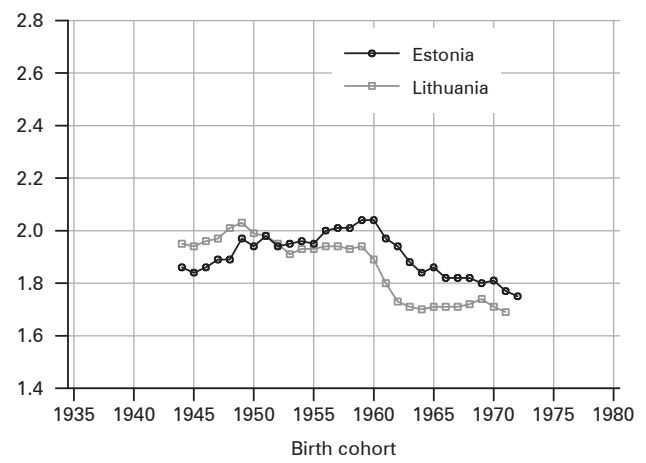

Source: Human Fertility Database 2014, Observatoire Démographique Européen 2012, Warsaw School of Economics 2014: Personal communication 
Tab. 2: Cohort total fertility rates at age 40, selected Central and East European countries, birth cohorts 1957 and around 1970

\begin{tabular}{|c|c|c|c|c|}
\hline \multirow[t]{2}{*}{ Region, Country } & \multicolumn{4}{|c|}{ Cohort total fertility rate at age 40} \\
\hline & 1957 & $\begin{array}{l}\text { Latest recorded } \\
\text { around } 1970 \\
\text { cohort }\end{array}$ & $\begin{array}{l}\text { Birth } \\
\text { cohort }\end{array}$ & $\begin{array}{l}\text { Percent change } \\
1957 \text { to circa } \\
1970 \text { cohort }\end{array}$ \\
\hline \multicolumn{5}{|l|}{ Central Europe } \\
\hline Croatia & 1.92 & 1.82 & 1966 & -5 \\
\hline Czech Republic & 2.06 & 1.84 & 1971 & -11 \\
\hline Hungary & 2.00 & 1.87 & 1969 & -7 \\
\hline Poland & 2.17 & 1.66 & 1972 & -24 \\
\hline Slovakia & 2.19 & 1.77 & 1973 & -19 \\
\hline Slovenia & 1.93 & 1.65 & 1973 & -15 \\
\hline \multicolumn{5}{|c|}{ South-Eastern Europe } \\
\hline Bulgaria & 2.03 & 1.67 & 1969 & -18 \\
\hline Serbia & 1.81 & 1.55 & 1975 & -14 \\
\hline Romania & 2.23 & 1.80 & 1966 & -19 \\
\hline \multicolumn{5}{|l|}{ Eastern Europe } \\
\hline Belarus & 1.91 & 1.56 & 1972 & -19 \\
\hline Russia & 1.86 & 1.57 & 1970 & -16 \\
\hline Ukraine & 1.83 & 1.52 & 1971 & -17 \\
\hline \multicolumn{5}{|l|}{ Baltic States } \\
\hline Estonia & 2.01 & 1.75 & 1972 & -13 \\
\hline Lithuania & 1.95 & 1.69 & 1970 & -13 \\
\hline
\end{tabular}

Source: Human Fertility Database 2015, Observatoire Démographique Européen 2012, Warsaw School of Economics 2014: Personal communication

An investigation of Sobotka and Zeman $(2014)^{6}$ demonstrated that the cohort fertility decline continued among the 1970s cohorts in most CEE countries. These authors calculated completed cohort fertility rates for 26 European countries for the 1965 to 1974 birth cohorts, including eight CEE countries. ${ }^{7}$ On average, the 1965 CTFR of 1.93 births per woman for the eight CEE countries declined to 1.71 births per woman in the 1974 cohort: an 11 percent decline.

Myrskylä et al. (2013) prepared a new set of CTFR forecasts for 37 developed countries for the 1970s cohorts which included 11 CEE countries. An increase was estimated for Lithuania, Russia, East Germany, Slovenia, Estonia and Bulgaria. On the other hand, decreases were estimated for Romania, the Czech Republic, Poland, Slovakia and Hungary. As the declines were larger than the increases, the average

6 Sobotka, Tomáš; Zeman, Kryštof 2014: Personal communication 10 October.

7 The eight CEE countries are the Czech Republic, Hungary, Latvia, Lithuania, Poland, Romania, Slovakia and Slovenia. 
1970 CTFR of 1.75 for these countries declined to 1.68 births per woman for the 1979 birth cohort.

Other evidence validates the assumption of continued declines in CTFRs in most CEE countries. In countries with available data for analysis, ${ }^{8}$ results show that only a part of postponed births were being recuperated among the 1970s birth cohorts. Such a sequence virtually guarantees that CTFRs of subsequent cohorts will be smaller than in preceding cohorts. Table 3 provides an overview of recuperation indices (RI), i.e. of the amounts of childbearing that have been recuperated relative to the fertility decline at younger ages ${ }^{9}$ between the 1970 and the 1975 birth cohorts. The recuperation index is usually computed for cohorts that have (almost) completed their childbearing periods. In Table 3 the Rls are computed for incomplete cohorts and the highest ages these cohorts have reached are listed. In other words, the Rls are merely an indication of whether eventually the respective cohort might recuperate the full amount of postponed births. Taking the example of Poland, if by age 36 the 1975 birth cohort has recuperated only 35 percent of the postponed births compared to the 1970 cohort, it is almost certain that women born in 1975 will not recuperate 100 percent of the postponed births by the time they reach the end of their reproductive period. The numbers in Table 3 and the graphs in Figure 4 illustrate that the probability of women in the 1975 birth cohorts recuperating all the postponed births in the listed countries is low. ${ }^{10}$

Tab. 3: Recuperation indices (in percent) between birth cohorts 1970 and 1975, 1970 CTFR (40), selected Central and East European countries

\begin{tabular}{lccc}
\hline Country & $\begin{array}{c}\text { Recuperation Index between birth } \\
\text { cohorts } 1970 \text { and } \begin{array}{c}1975 \\
\text { RI }\end{array}\end{array}$ & $\begin{array}{c}1970 \\
\text { CTFR at } \\
\text { age } 40\end{array}$ \\
\hline Czech Republic & 64 & 35 & 1.85 \\
Poland & 35 & 36 & 1.78 \\
Estonia & 77 & 36 & 1.82 \\
Belarus & 47 & 36 & 1.64 \\
\hline
\end{tabular}

Note: The Recuperation Index (RI) measures the degree of fertility recuperation relative to the fertility decline at younger ages.

Source: Human Fertility Database 2014, Warsaw School of Economics 2014: Personal communication

8 The analysis was carried out only when cohort fertility was registered at least up to the age of 35 .

9 For instance, in the Czech Republic minus 0.433 births per woman at age 25 was the difference of the cumulated ASFRs between the 1970 and the 1975 cohorts (Fig. 4, panel A). By age 35 the difference between the two curves was -0.155 , which means that 0.278 births per woman had been recuperated, thus only 64 percent of the births that were postponed by age 25 were recuperated by age $35[0.433-0.155=0.278 / 0.433=0.64]$ (Table 3$)$.

10 There were two exceptions when the Rls for the 1980 cohort were high, namely in Estonia (101 percent) and Belarus (127 percent), and thus in these countries completed cohort fertility rates for the 1980 cohort will eventually exceed those of the 1975 cohorts (Fig. 4). 


\subsubsection{Cohort parity distributions}

The palpable fertility quantum decline during the CEE societal transitions is also illustrated by trends in cohort parity distributions in nine countries (Fig. 3). There was a distinct decline in the share of women with two children and an increase in the share of women with one child among the 1960s cohorts. Second order parity women still dominated in almost all countries in the 1970 birth cohort, although there were already more women that had had one rather than two births in Russia and Ukraine. It should also be emphasized that shares of women remaining childless even in the 1970 cohort remained low, i.e. at around ten percent or less.

The notable fertility quantum decline between the 1960 and the 1970 cohorts in these nine countries is reflected in a dramatic increase of the ratio of shares of low order parities (childless and women with one birth) compared to high order parities of women who had borne three or more children (Appendix Table 5). In the Czech Republic, for instance, there were about as many low parity women as there were women with $3+$ children in the 1960 cohort, and this ratio increased to 1.7 in the 1970 cohort. In Bulgaria, Belarus, Russia and Ukraine among the 1970 cohorts there were around four or more times as many women of low order ( 0 and 1 ) parity compared to those of high order parity $(3+)$.

\subsubsection{The recent slowdown in childbearing postponement}

Some evidence indicates fertility postponement was slowing down in the 2010s and in the birth cohorts of the 1970s and early 1980s. To begin with, the mean age of women at first birth was no longer increasing or had tapered off in South-Eastern Europe, the Baltic States, and in some other countries (Appendix Fig. 2). Further, the cohort age patterns of childbearing were no longer changing very much among the 1980s birth cohorts (Appendix Fig. 4).

The clearest evidence of a slowdown in childbearing postponement is apparent in Figure 4. A comparison of the curves of differences between cumulated ASFRs of young birth cohorts five years apart shows that the lowest points in the curves are diminishing. For instance, the nadir in the difference between the 1970 and the 1975 cohorts in the Czech Republic was over -0.4 births per woman, whereas for the difference between the 1975 and the 1980 cohorts it was less than -0.3 births per woman. Except for Lithuania, the same pattern is repeated in all populations in Figure 4, as well as in those not included in Figure 4. Furthermore, the downward slope of the beginning of the curves of differences between the 1975 and the 1980 cohorts, as well as differences between the 1980 and the 1985 cohorts are less steep than the downward slope for the preceding curves.

The slowdown in childbearing postponement should pose upward pressure on the PTFR. One could hypothesize that the petering out of the PTFR recuperation around 2010 was due to a countervailing effect of declining fertility quantum, i.e. of the declining CTFRs (Cf. section 4.2.5). 


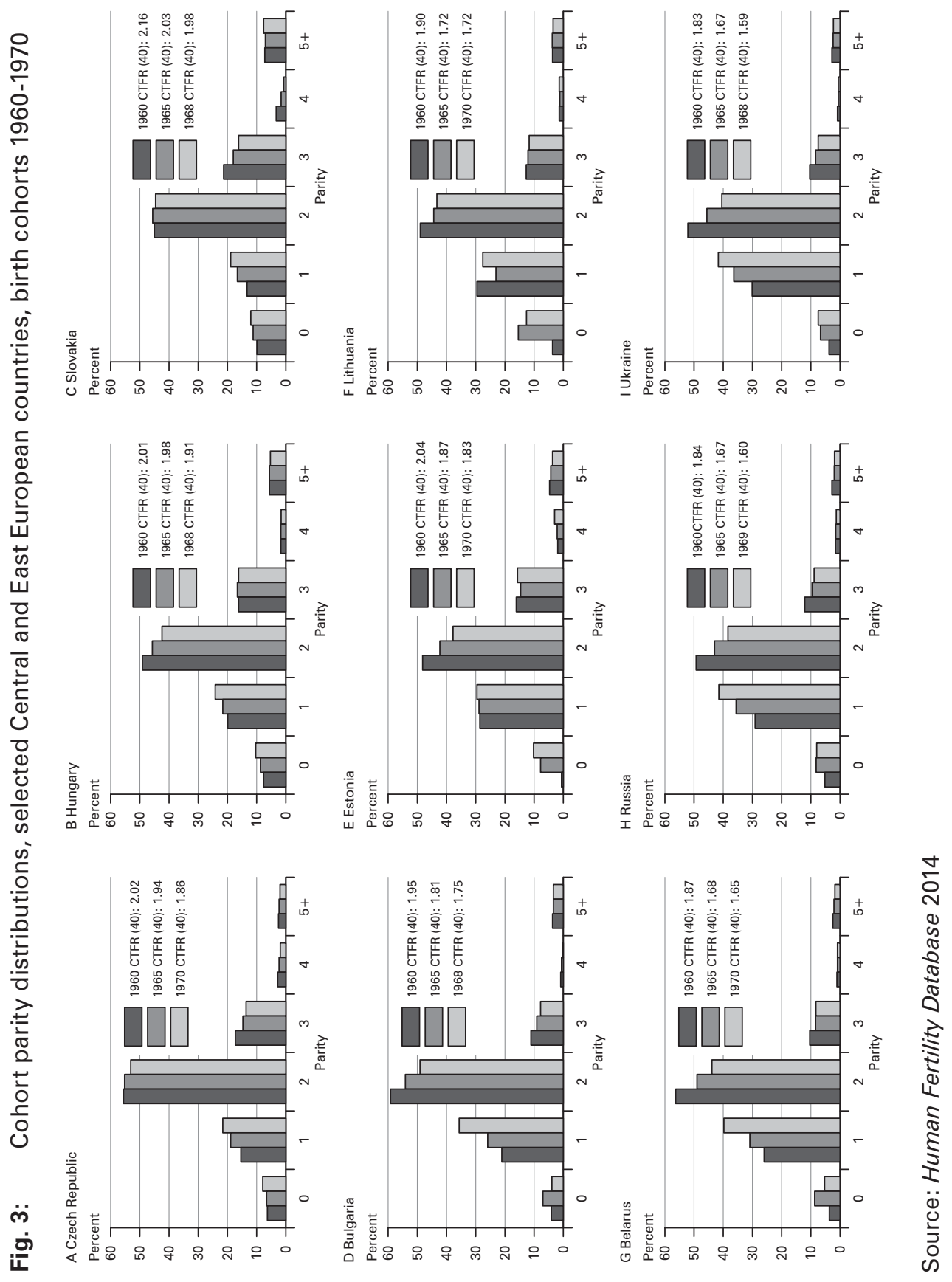


Fig. 4: Differences in cumulated age-specific cohort fertility rates between moving benchmark cohorts and subsequent cohorts five years apart, Czech Republic, Poland, Estonia, and Belarus, birth cohorts 1970, 1975, 1980 and 1985
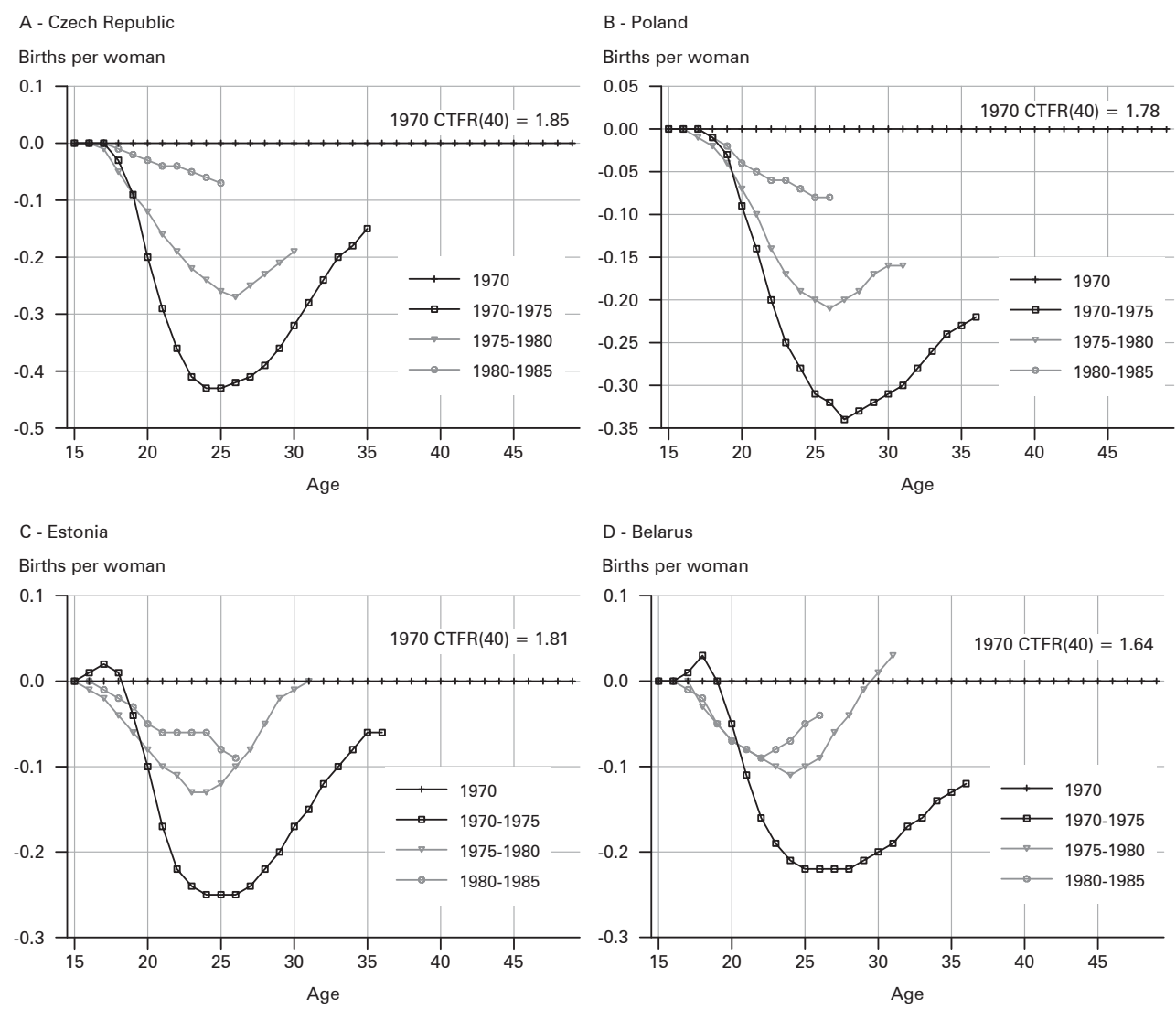

Source: Human Fertility Database 2014; Warsaw School of Economics 2014: Personal communication

\subsubsection{National population projections}

As discussed in section 2 (Background), populations were shrinking in almost all CEE countries during the societal transformations of the 1990s and 2000s. This was due to low fertility, often reinforced by emigration and relatively high mortality. According to official population projections prepared by national statistical offices, population decline is projected to continue in the future ${ }^{11}$ (Appendix Table 6).

11 Specific data in the medium variant projections prepared by the United Nations Population Division (2015) differ, however by the middle of the $21^{\text {st }}$ century decline is projected in all 15 countries. 
These projections illustrate the implications of assumptions made by national experts about future fertility and migration trends. Although methods used differ from one country to another, the projected numbers for the near future (up to 20 years) indicate the direction of growth reasonably well. A brief discussion of fertility and migration assumptions enables a better understanding of the projections. Nonetheless, as is well known from historical experience, caution is in place when dealing with population projections.

Fertility assumptions necessarily begin with levels from the early 2010s and do not change rapidly. It is more likely that migration assumptions do not materialize, if for no other reason than that knowledge about actual migration trends is questionable.

Belarus, Bulgaria and Estonia assume net emigration, which means that projected population decline is reinforced by migration assumptions. The projections for the Czech Republic, the Russian Federation, Serbia, Slovakia and Ukraine assume net immigration. These assumptions would partly offset the effect of low fertility assumptions on future population trends. With this knowledge in mind, if immigration is weaker or emigration stronger than assumed, projected population numbers for the latter countries would be smaller than indicated in Appendix Table 6.

As it stands, the only population where the projections show any population increase is Slovakia. Slovakia is, however, one of the countries assuming considerable immigration inherent in the population projections. Similarly, projections for Russia and the Czech Republic assume considerable immigration. In other words, all the medium variants of official population projections for the countries in Appendix Table 5 indicate the possibility of declining populations in the future, even though migration assumptions could prove to be unrealistic. Slovakia might be the exception because its population age structure contains a growth momentum driven by past high fertility.

In sum, the projections suggest that declining populations can be expected in almost all CEE countries while keeping in mind the hypothetical nature of projections.

\section{$5 \quad$ Family policies in Central and Eastern Europe}

\subsection{The forming of post-communist family policies}

Post-communist family policies in CEE were formed at a time of historic vicissitudes in the "indirect and proximate" determinants of fertility (Davis/Blake 1956; Bongaarts 1978). These were the tumultuous two decades after 1990 of major economic, social, political and cultural change discussed in preceding sections. Accordingly, the "indirect" fertility determinants of that time exerted a strong downward pressure on childbearing. At the same time, the means being employed to modify childbearing were also undergoing major changes. It was the time when the "abortion culture" was being replaced by a rapid introduction of modern contraceptives which in most CEE countries were considered a bourgeois feature by the communist establishment. Contraceptive prevalence of modern methods was on the rise, prevalence of 
traditional methods was declining throughout CEE (Appendix table 7), and induced abortion rates were abating (Appendix table 8). Period and cohort fertility were declining rapidly (Cf. sections 4.2.1 and 4.2.5).

In the immediate aftermath of the demise of state socialism governments were preoccupied with economic and political reforms and did not pay much attention to social and family policies. A part of the pro-natalist communist policy measures, such as parental leaves and child benefits remained in place, but effectiveness was waning due to inflation. Relatively high costs were causing restrictions of child care facilities. Other policies were being abandoned altogether, most notably the influential housing policy of preferential assignment of apartments to families with children (Frejka 2008; Sobotka 2011).

As fertility was rapidly declining governments increasingly turned their attention to social and family policies. As documented below in section 5.3 Country family policy profiles, in several CEE countries governments intended to design and implement comprehensive family policies that would minimize the employmentchildrearing dilemma. Documents were formulated, commissions and ministries founded to achieve this goal. An examination of the status of family policies around 2013-2015 in CEE countries points to four types of family policies.

\section{Comprehensive family policy model}

Governments have managed to create reasonably favourable conditions for women and men to ameliorate the difficulties associated with taking care of children and households, as well as being employed. Not only are financial and material benefits available for mothers and fathers, but also institutional childcare is adequate as are working conditions for mothers. Gender relationships are improving, although a lot still remains to be desired. The overall picture indicates that Estonia and Slovenia qualify for this model. Interestingly, cohort fertility around the 1970 cohort in these two countries was not higher than the average in the Baltic and Central European countries.

2. Pro-natalist policies model

The pro-natalist model comprises countries in which the main objective of family policies is to raise fertility and the principal tools to reach this goal are financial. The countries which in one form or another have introduced large birth allowances, possibly in combination with increasing other benefits and with well remunerated parental leaves fit into this category: the Russian Federation, Belarus, Ukraine and possibly Bulgaria as well as Latvia.

3. Temporary male bread-winner model

Well-remunerated long parental leaves were common under the state-socialist regimes. In some countries, these were retained and prolonged while childcare for small children under age three has dissipated and is virtually non-existent. Employers tend to discriminate against mothers and potential mothers, and their working conditions make it difficult to balance employment and household responsibilities with scarce possibilities for part-time work. This situation is typical in the Czech Republic and Slovakia. This model might have developed unintentionally, but has become a reality.

4. Conventional family policies model.

The conventional model consists of a combination of maternal leaves, child benefits, and child care facilities which provide some support for childrear- 
ing, however the extent of assistance is not sufficient to alleviate the employment-childrearing dilemma. That state of affairs persists in Croatia, Lithuania, Poland, Romania, and Serbia, and to some extent in Hungary. The specific configuration differs from one country to another. Also the principal circumstances that have generated the respective conditions differ.

\subsection{A Brief historical perspective}

Family policies were first comprehensively elaborated in a 1934 book Crisis in the Population Question by A/va and Gunnar Myrdal (1934). Their ideas played a major role in designing welfare policies in Scandinavia, and after the Second World War in Western Europe. Since then numerous authors have dealt with population and family policies in industrialized countries, including Eastern Europe (for instance, Besemeres 1980, 24 scholars in Berelson 1974, David and Mclntyre 1981, 14 scholars in David 1999, Neyer 2003, about 50 scholars in Frejka et al. 2008). McDonald (2002) and Stock et al. (2013) devised frameworks to guide the formulation of contemporary family policies.

Family policies of contemporary, mainly western developed countries have also been thoughtfully and thoroughly investigated and categorized by Gauthier (2002) and Thévenon (2011). However, not a single CEE country was included in Gauthier's analysis and only four CEE countries were included in Thévenon's.

The present overview and analysis of family policies in the formerly socialist countries of CEE constitutes a complement to the extant literature on this subject matter.

\subsection{Country family policy profiles}

The CEE family policies typology is derived from a thorough analysis of family policies in the individual countries by teams of country collaborators. Concise descriptions and analyses of family policies in these 15 Central and East European countries $^{12}$ follow.

\subsubsection{Belarus}

Low fertility is a high priority in both the political and public discourse in Belarus. Concern is reflected in official documents as well as in opinion surveys. The $\mathrm{Na}$ tional Programme of Demographic Security of Belarus for 2011 - 2015 is the most recent in a series promulgated by the government. In it "the demographic situation in the country is characterized by a steady depopulation since the early 1990s. The main factor of depopulation in the Republic of Belarus is a low birth rate." Specific policy measures are centred on child and birth allowances. A lump sum payment

12 More information is available in Barnett Papers in Social Research 15-01 (Basten/Frejka 2015) and detailed descriptions of country family policies will be available in the University of Oxford CEEfamily Working Papers (see ceefamily.info). 
is made for each birth. As of 2014, this payment amounts to the equivalent of€828 for the first birth; for the second and subsequent births it rises to $€ 1159$. A universal care benefit for a child under three years is paid at 35 percent of the average wage (€408) for the first child (€143 in 2014) and at 40 percent for the second and subsequent children (€163). These measures possibly entailed an increase in the period TFR which increased from 1.23 in 2004 and 1.50 in 2010 to 1.66 in 2013.

The main emphasis of family policies is on financial incentives. Little attention is devoted to other important family policy issues, such as amelioration of the work/ household responsibilities dilemma of women; gender equity at home and at work; institutional child-care; and housing conditions. Altogether family policies in Belarus are of a relatively narrowly conceived pro-natalist nature.

\subsubsection{Bulgaria}

Bulgaria's population strategy was set out in a 2005 document National Strategy for Demographic Development in the Republic of Bulgaria for the Period 2006 - 2020. The goals include: to encourage fertility through providing facilities necessary for raising children; to discourage reproductive-aged people from emigrating; to improve reproductive health and to prevent sterility. The following measures were considered: further development of gender equality; financial support for raising children, especially for a second child; better opportunities for work-family reconciliation; the introduction of services that support raising children in the family environment; improvements to the educational system; better infrastructure and living environments; family planning consultations free of charge; and cultivating the two-child family model.

Fertility policies in Bulgaria aim to increase second births. Payments at birth differ by parity: 2nd child $600 \mathrm{BGN} / € 300$, $€ 125$ for the $1^{\text {st }}$ and $€ 100$ for the $3^{\text {rd }}$ child. Monthly childcare allowances are higher for the second child than for first or third child. Students are encouraged to combine studies with parenting via a high birth allowance of $€ 1,440$ (for comparison, the average monthly salary in January-September 2014 was 807 BGN/€404).

Maternity leave is 410 days during which mothers who worked for at least 12 months prior to the birth receive 90 percent of their gross salary. Following that, mothers are entitled to leave with an allowance equal to the minimum monthly wage until their child is two years old. Mothers have the legal right to an additional year of parental leave without allowance until the child's third birthday.

Institutions of childcare consist of public crèches for children aged 10 months - 3 years, and kindergarten for children aged 3 to 6 . Pre-school education is obligatory for children above age 5 and is free of charge. In the view of the team of country collaborators family policies in Bulgaria are directed towards financial help for families with children in need. It is questionable whether the monetary measures fulfil the aim of increasing fertility in Bulgaria. Not enough is done to improve the institutional support for parents. In most cities, there are fewer places in nurseries and kindergartens than are needed. Very little is done to reconcile family and work. When mothers return to work they work full time. Other work schedules are not tolerated. 
In sum, the rhetoric of family policies is comprehensive. In reality the focus is limited to financial support, including a long maternal and parental leave. Bulgarian family policy can therefore be labelled as pro-natalist. Little attention is devoted to numerous unresolved issues: insufficient infrastructure of childcare; limited attention to ameliorate the work-family dilemma; high unemployment and low incomes.

\subsubsection{Croatia}

Since 1995, Croatia has formally ratified several documents concerning demographic policy with the goal to encourage an increase in fertility. The National Population Policy was introduced in 2006. This document was formulated in the spirit of familyfriendly policies with many lofty goals, such as facilitating housing and employment for young families, and licensing of trained and available babysitters. The majority of these goals proved to be unrealistic.

Extant family policy measures include: a maternity leave of 180 days; child benefits which are somewhat higher for third and fourth births; and childcare facilities that are attended by over 40 percent of children of preschool age. Economic difficulties are believed to be among the challenges people are facing when deciding about having a child, and these are also limiting the government's resources for social policies. A high unemployment rate, uneven regional development and a challenging investment climate are the main economic problems. Gender equality is advancing at a slow pace. Housework and child-care are still considered mostly women's responsibilities and women indeed perform most of the housework regardless of their employment status.

Ilišin et al. (2013) conducted an extensive study focusing on young people's lives. Respondents were aged 14 to 27 , most of them still in school. The share of unemployed (approximately one fourth) is almost equal to those with a job (approximately one third). For the most part, young people live with their parents because of insufficient financial resources. The main professional goal of young people is to find a secure job and many are looking for employment abroad.

In sum, the Croatian government has published several family policy documents in recent years, but the majority of policy recommendations proposed have not been implemented. This inaction has been attributed to a lack of financial resources for families and institutions.

\subsubsection{Czech Republic}

In the Czech Republic, three periods of implementing family policies after 1989 can be distinguished.

\section{Policy reorientations in the 1990s:}

The pro-natalist nature of family policies was abandoned. Policies became mostly based on broader social welfare concerns aimed at reducing income inequality, and preventing poverty. Special attention has been devoted to parental leave policies. The Czech Republic has one of the longest parental leave periods. It was expanded 
until a child's $4^{\text {th }}$ birthday in 1995, although it does not align with the length of the job protection period fixed at three years. Low priority was given to women's employment with some strengthening of the male breadwinner model and a preference for mothers of small children to perform childrearing at home. Public childcare for children below age three collapsed in the 1990s as expensive-to-operate crèches faced a declining demand and became a rising financial burden. There was also a huge expansion in the availability of contraception. A payment was introduced for induced abortions and these declined sharply. Housing was partly privatized and was in short supply.

\section{1998-2008: Gradually increased attention to family policies:}

The establishment of the Department of Family Policy and Social Work at the Ministry of Labour and Social Affairs demonstrates the Czech Republic's concern to support the EU agenda to promote family policies and gender equality. Birth and parental leave allowances were doubled in 2006-7.

\section{2009-2013: Cuts and reforms of family support:}

The amount of birth allowance was curtailed in 2008. Subsequently, it became means tested and since 2010 provided only for the first child. On the positive side, parents gained more flexibility in parental leave. Since 2012, they can decide about its duration and leave payment period (19-48 months), with a fixed total sum of 8,000 EUR (2014) distributed in monthly installments.

The current family policies combine an entitlement for a long period of parental leave with a low availability of early childcare, nurturing a de facto male breadwinner model among families with children aged $0-3$. There are limited options for parents to reduce work hours or work part-time. The policy of equal opportunities for men and women has only minor political and public support. Altogether, this creates a paradoxical dichotomy for most women experiencing a complete withdrawal from the labour market for 3 years after childbirth followed by a return to full-time labour participation thereafter. This cycle is typically repeated when another child is born and leads to the loss of skills and income among working mothers.

\subsubsection{Estonia}

A policy document Smart Parents, Great Children, Strong Society: Strategy of Children and Families 2012-2020 was ratified in Estonia in 2011. It demonstrates the government's thorough understanding of modern comprehensive family policies. The document lists basic demographic challenges: the population is aging; the working-age population is decreasing; and the number of births is small. One approach to cope with these challenges is to make Estonia a family-friendly country. The Strategy of Children and Families focuses on prevention and early intervention at all levels, which requires an agreement between political parties about the main principles that guarantee the wellbeing of children and families. The main objective of the strategy is to improve the wellbeing and quality of life of children and fami- 
lies, thereby promoting the birth of children. The strategy aims to narrow the gap between the desired and actual number of children born.

Estonia has a universal family benefits system. It includes birth allowances, child allowances, maternity leave, paternity leave, parental leave, childcare allowances, a variety of targeted family benefits, a tax allowance, and childcare facilities. Spending on social protection benefits for families amounted to 2 percent of GDP in 2011, slightly less than the EU average of 2.2 percent. In recent years, there has been increasing recognition that universal measures should be supplemented with a stronger package of means-tested measures to reduce child poverty.

In the system of policy measures some stand out as being particularly helpful:

Child care facilities: In 2012, 20 percent of 1-year-olds, 70 percent of 2-yearolds, 90 percent of 3-4-year-olds and more than 90 percent of 5-6-year-olds attended public childcare. Children typically attend on a full-time basis, i.e. 35-40 hours per week.

Parental leave: New provisions include benefits equalling 100 percent of income earned during the calendar year preceding childbirth; the maximum amount is three times the average salary. In 2004, the duration of benefit payment was set at 11 months following childbirth. In 2006, it was extended to 14 months, and in 2008 up to 18 months.

\subsubsection{Hungary}

Hungarian family policies originated in the pre-transition period. Frequent changes in regulations and benefit levels have occurred, because political parties alternating in government had contrasting family policy philosophies. As of 2013, Hungary had a complex system of birth and child allowances, as well as a comprehensive system of maternity and parental leave. The total entitlement of paid leave for mothers was 160 weeks, which consisted of 24 weeks of maternal leave and 136 weeks of parental leave.

The following specific universal benefits are available:

Birth grant: a one-off payment of 64,125 HUF/€209. "Baby bond": a one-off payment of $42,500 \mathrm{HUF} / € 168$ into a bank account kept until the 18th birthday of the child by the Hungarian State Treasury with the option for parents and the government to make further payments into this account. Child home care allowance: 28,500 HUF/€93 per child per month, claimed until the third birthday. Child raising support: 28,500 HUF/€93 per month for mothers (or fathers) who raise three or more children under the age of 18 until the youngest child is three to eight years old. Family allowance: A monthly family allowance until the end of a child's school education, at most up to child's $20^{\text {th }}$ birthday - 12,200 HUF/€40. Family tax allowance: Is subtracted from the tax base; for one or two children a deduction of 10,000 HUF/€33 per child, for $3+$ children a deduction of $33,000 \mathrm{HUF} / € 107$ per child. Public childcare: For children under the age of 3 , nursery is available, although coverage barely exceeds 10 percent and facilities tend to be overcrowded. Family day care, where a maximum of five children can be taken care of, is for children between 20 weeks and 14 years. Moreover, several insurance based benefits (e.g. maternity benefit and parental benefit) are available to women who have been employed for at least 
365 days in the two years preceding the birth of the child. In recent years, eligibility criteria for parental benefit have been extended to include women in higher education and those who go back to work after the first birthday of the child.

Spéder and Kamarás (2008) observed that "population policy was basically zigzagging in the 15 years following the change of political regime in 1989/1990, and it often became the key issue of political struggles (...) a significant fluctuation characterized Hungarian family policy after 1990; the basic principles of support changed often and profoundly. (...) Therefore, family policy and levels of child-related supports were highly unpredictable." And continue to be so.

\subsubsection{Latvia}

A systematic concern for family policies is evident in Latvia's recent history. In 2004 a Ministry for Children and Family Affairs was established and the government adopted an action plan "State Family Policy". The focus on demographic issues was strengthened when a Council on Demographic Affairs, chaired by the Prime Minister was established in 2011. Family State Policy Guidelines for 2011 - 2017 were adopted in 2011. The government aims to facilitate family formation, to fortify their stability and wellbeing, to increase fertility, as well as to strengthen marriage as the best form of family and to improve the value of marriage. In 2014 a focus on family policies was strengthened within the framework of the 2015 - 2017 budgetary planning.

Latvia has a universal family benefits system. In 2013 public financing for family policies in Latvia was 2 percent of GDP, and this is expected to increase to 2.252.5 percent of GDP by 2015. The main benefits consist of: a child birth benefit of $€$ 421.17; a monthly family state benefit of $€ 11.38$ for each child aged 1-15 and 15-19 if in school, twice this amount for the second child and three times for subsequent children; a child care benefit of $€ 171 /$ month up to age $1.5 ; € 42.69 /$ month for ages 1.5-2; a parental benefit paid to an insured person who is taking care of a child younger than 1 or 1.5 years provided this person is employed on the day the benefit is approved and is on leave for child care (the average amount in 2014 was $€ 501.50$ ); a maternity leave granted to expectant mothers who are employed and receive a salary, are self-employed, or are spouses of a self-employed person and have voluntarily joined the social insurance, the length of maternity leave is 112-140 days.

Early childhood education which includes safe and quality childcare services is provided by local municipalities free of charge for children from 1.5 years until compulsory school age (7), but availability does not meet the needs of all parents. A variety of flexible childcare services have been introduced such as private childcare institutions. More than 90 percent of the total number of children aged 3-6 were enrolled in pre-school education institutions in recent years. Childcare services have been provided for more than 23 percent of children under the age of 3 . 


\subsubsection{Lithuania}

For the past 25 years, the design and implementation of family policies in Lithuania has been marked by a struggle of competing ideologies. The support for the malebreadwinner family model and corresponding financial measures have been supplemented by family policy instruments that reinforce gender equality, work-family balance and better employment opportunities. Often the ideological positions and implemented policies did not correspond to the traditional political right and left wing divide.

While there is no clear family policy strategy, a parental (maternity/paternity) leave benefit, which has been subject to multiple modifications in recent years, continues to be the principal measure supporting families with children. Since July 2011 parents are granted a choice between a one- and a two-year payment period. The former provides a benefit covering 100 percent of the compensatory wage, the latter covers 70 percent of the compensatory wage during the first year and 40 percent during the second year. A 2012 survey revealed that the availability and quality of formal childcare services, particularly for children under 3 years of age, remains a very important territorially highly differentiated issue. Nonetheless, over 30 percent of children under the age of three were attending crèches and over 80 percent of children aged 3-6 were enrolled in formal childcare.

Findings from surveys conducted between 1994 and 2010 show that not only has fertility decreased in Lithuania but citizens' desires to have children have declined. During the 15 years since the mid-1990s the mean desired number of children among the 18-49 year-olds (both men and women) who already have and/or desire to have children has fallen from 2.09 in 1994-1995 to 1.99 in 2010. The mean number of intended children declined from 1.91 in 2001 to 1.75 in 2010. As the actual number of children is usually smaller than the intended number, positive fertility changes are hardly to be expected.

As parties have alternated in government and economic conditions have been unstable, family policy measures have been subject to frequent adjustments. The discontinuity and instability of family policies limited the chances to achieve a positive effect of the adopted family policy measures.

\subsubsection{Poland}

In the 1990s the Polish government's involvement in family policy regulations was to delegate responsibility for family's wellbeing to parents; to delegate responsibilities for social policies to local governments; and to commercialize social services. The fertility decline was initially perceived as a temporary reaction to the transformation process. Government family policy programmes did not stop the downward fertility trend, neither did the reversal of the liberal induced abortion legislation in 1993 which implied a de facto ban of abortions for most women. Financial support was largely restricted to low-income households and family benefits were primarily a tool to prevent poverty rather than to assist families with their child-related costs. 
During the 2000s, low fertility became a concern addressed in public debate, however, there was no common political understanding how to respond to ongoing family changes. Policy changes after 2003 can be viewed as a gradual shift towards more generous financial support and towards helping dual-earner families. Especially, since 2008 revisions in leave schemes, tax reductions and regulations on early education and care provision slightly improved parents' possibilities to combine work and care obligations. In 2013, an additional family leave of 26 weeks to be used after maternity leave, paid at 60 percent of salary, extended possibilities for working parents to provide care during the first year of childrearing. Further amendments to the parental leave scheme implemented in July 2015 also aim to make it more flexible for parents and thus easier to reconcile work and care.

Despite these recent changes in family policy, Poland still lacks a stable comprehensive family policy that matches the aspirations of its citizens and the needs of young people. The family policy programme announced by the President's office in 2013 and the population-related policy proposed by the Government Population Council in 2012 haven't been discussed by the government. However, some measures implemented by the government recently reflect their policy recommendations.

Referring to the existing fertility gap, scholars identified the main obstacles to achieving fertility intentions:

- Difficulties to reconcile work and family duties due to shortages in early childhood education and care services for children aged 0-5; high costs of these services which are ill-adjusted to parent's needs; the way teaching and nonteaching activities are scheduled in primary schools; non-flexible work patterns;

- Increasing direct costs of children, affected by both quality shifts in parent's aspiration and rising costs of education;

- Income instability, unemployment threats and difficulties faced by young people in obtaining employment as well as low financial transfers to families;

- Difficulties obtaining housing;

- Gender gaps in sharing household duties between men and women;

- Insufficient knowledge about reproductive health, including lack of support for couples facing troubles to become parents.

Altogether, parents are confronted with high direct and indirect costs of children while the state's contribution towards parenthood is still low despite its notable increase over the most recent eight years, i.e. since the late 2000s. Moreover, family policy is exposed to political instability due to a strong ideological component involved in the family policy debates.

\subsubsection{Romania}

Romania has been experiencing serious political and economic instability. During the past six years, i.e. since 2010, there were seven different governments. In this environment only limited attention has been devoted to family policy issues. More- 
over, because childbearing was previously enforced with drastic measures, namely the prohibition of contraceptives and induced abortions, the state is reluctant to deal with family policy issues.

The majority of social benefits aim to alleviate poverty. The economic decline caused a reduction in government revenue and spending. Consequently, funds for social policy not oriented towards poverty reduction or economic development are scarce. Nonetheless, a range of birth and child allowances are in place, including two different ways of receiving parental leave and benefits for raising a child. Parents can decide whether they wish to obtain parental leave until the child is either 12 or 24 months old with a child raising allowance adjusted according to the length of the leave.

In 2012, 56.5 percent of mothers with children under six were employed. Formal childcare, however, was available in 2011 to merely 2 percent of children under the age of three and to 41 percent of children between three and the minimum compulsory school age.

Childbearing intentions are low. According to the Generations and Gender Survey of 2005, among respondents that already have more than one child, only 2.6 percent of women and 4.6 percent of men want another child.

Altogether, the existing family policy measures are not sufficiently effective to act as an inducement to childbearing, since they cover only a minor share of the costs. Also, adequate attention is lacking to the various issues of a more comprehensive substance of family policies, such as gender equality, flexibility of working conditions and dealing with the work/care dilemma.

\subsubsection{Russian Federation}

Traditionally, material incentives, especially monetary ones, have been and continue to be the main tool of pro-natalist endeavours within the Russian Federation since they were first adopted in the 1930s. As period fertility rates plummeted in the 1990s, once again, concern for low fertility led president Putin to implement pronatalist policies that came into effect on 1 January 2007:

- A substantial increase in pregnancy, birth, and child benefits progressively graded by child order;

- A parental leave of over 5 months at 100 percent of annual salary; up to 18 months of leave partially remunerated; up to 3 years of unpaid leave;

- A "maternal capital" granted to mothers of second and higher-order children for the acquisition of housing, the education of children, and to augment the mother's pension. Initially 250,000 rubles, indexed to inflation which grew to 387,640 rubles in 2012 , approximately US $\$ 12,000$ at the then-current exchange rate.

The share of family support in GDP roughly doubled, approaching 1 percent. The policies did have an immediate effect. The PTFR grew from 1.31 in 2006 to 1.75 in 2014. The real effect will only become evident in $15-20$ years when data become 
available for cohorts that were in the midst of their childbearing in the 2000 s, i.e. mainly women born during the late 1970s and the 1980s.

There are some signs indicating these policies had only a limited effect:

An analysis of the 2006-14 PTFRs illustrates that the effects appear to be wearing off over time; intentions to have additional children did not change in the three waves of the Generations and Gender Survey (2004, 2007, 2011); alternative scenario methods indicated that the number of births per woman for the 1970s and 1980s birth cohorts is likely to remain stable rather than resulting in a desired increase; analyses revealed that the PTFR growth was due to a slowdown in childbearing postponement (Frejka/Zakharov 2013). The overall tentative conclusion is that the 2007 policy measures did not raise cohort fertility.

The official position of the Putin administration is that measures to stimulate the birth rate have been an unqualified success. However, even experts involved in policy making have expressed caution. One of these, Rybakovsky (2012) expressed doubt that current pro-natalist measures can continue to deliver results. He proposed to increase the grant for the third child, to introduce measures to lower the age at marriage, and to encourage the early birth of the first child.

\subsubsection{Serbia}

In Serbia, low fertility has been an enduring concern of the government, the media, and the public. The government espoused a Pro-natalist Strategy in 2008 stipulating the goal of reaching a "total fertility cohort rate at the level of 2.1 children per woman." The document outlined a comprehensive programme but it remained a declaration and few of the policy recommendations were adopted in practice. Similarly, a Council for Population Policy was established but it never functioned in reality. Although the leading party is in a firm political position, the government is confronted with many challenges and a dire economic situation.

A range of family policy measures are in place: full compensation of salary of working mother/father during parental leave for a period of one year for the first and second child, and two years for the third and every following child; a parental allowance for the first to fourth child; a child allowance for families in need of social protection; reimbursement for the cost of preschool establishments for children lacking parental care; abortion is available on request up to ten weeks gestation, and beyond ten weeks with the approval of a medical commission for women aged 16 or over; free contraceptive counselling once per year and free pregnancy care four times for normal pregnancies.

Gender relations are improving, but are still laden with male predominance, especially regarding employment. Young women are significantly hindered in their access to the labour market and are the first to be dismissed. Private companies have been known to ask potential female employees to sign a declaration they will not marry or have a child. Attention to reproductive health has been lacking. Only one in five women (18.4 percent) at risk of unplanned pregnancy used modern contraception in 2014 . The estimated total abortion rate was approximately 2.80 abortions per woman. 
Finally, no policies have been implemented to improve social and economic conditions of young people. The unemployment rate of young people aged 24-35 was 33.2 percent in 2012. Many young families reside with parents even after they got married and are expecting a child. As many as one in three households contain more than one family.

\subsubsection{Slovakia}

In Slovakia, family policies are marked by two distinct characteristics: Recurrent changes by parties alternating in power, and a long maternal leave combined with a substantial parental leave. The focus is more on financial transfers than on indirect measures of parental support. Persistent changes to various family benefits have made the system extremely complex. Low levels of stability have made it difficult for families to plan for the future.

Throughout the years of independence since 1993, the principal family policy measure was the combined long maternal and parental leave. As of 2014, the typical duration was up to 3 years of age. After frequent changes, there was only one amount of the parental allowance for all: $€ 204$ per month. Parents can decide to return to work earlier but in so doing forfeit the parental allowance, and might become eligible for a childcare allowance. The refunded amount for documented costs is up to $€ 230$, however, private childcare institutions are much more expensive than that. This policy effectively discourages women from gradually returning to the labour market and instead encourages them to remain at home for three or more years if they have more than one child.

There is also a shortage of childcare facilities for young children up to three years of age and, moreover, these facilities are expensive. Employers often discriminate against mothers of small children and against young women because of the expected three-year break associated with childbearing. Furthermore, unemployment of mothers after parental leave is high. These contributing factors lead many women to stay at home when they do have children or even discourages them from childbearing.

\subsubsection{Slovenia}

Family policies have attracted considerable attention in Slovenia since independence in 1990. The National Committee on Demographic Policy was established in 1994 and a Programme for Children and Youth 2006-2016 adopted in 2006.

There are three main components of family policy in Slovenia: An extensive and very well paid parental leave; a network of childcare facilities and highly subsidised programmes, and a relatively high child allowance for children in low-income families. Parental leave consists of 105 days of maternity leave, 260 days of parental and 90 days of paternity leave. Pre-school childcare almost completely meets the demand for children from age one to age six. The child allowance is received by a majority of children up to age of 18 and even up to age of 26 for those who are still in full-time education. In addition there is a birth grant, textbook funds, scholarships, 
subsidized transport for pupils and students, and subsidized school meals. There is also a system of child tax allowances which are progressive according to the number of dependent children.

Despite improvements in recent years, the traditional division of gender roles in Slovenian families persists, which leads to a "double burden" for employed women (Stropnik/Šircelj 2008).

Even though Slovenia has a relatively well-developed comprehensive family policy, research has not revealed any impact of individual family policy measures on people's fertility behaviour, except for a short-term effect related to a considerable prolongation of parental leave. At the same time, it is questionable what the fertility trend would have been in the absence of family policy. Undoubtedly, family policy has alleviated poverty in many families with children.

\subsubsection{Ukraine}

Since the mid-1990s a series of laws in Ukraine provide evidence that successive governments have been concerned with population issues and family policies. A key document which systematized and coordinated political and demographic undertakings The strategy of demographic development of Ukraine for 2005-2015 was adopted in 2006.

The birth allowance has been the principal family policy measure. It was increased from an insignificant amount in 2001-2002 to heights not seen in any other country. In 2014 the birth allowance for a first birth was UAH 30,960 (US\$3,259), for a second birth UAH 61,920 (US\$ 6,441) and for a third birth UAH 123,840 (US\$ $13,067)$. This was 40 percent higher than the per capita GDP at purchasing power parity in 2013.

Increases in the birth allowance along with some improvement in the socioeconomic situation and the recuperation of births that were delayed in the 1990s did have an effect on the period TFR; it increased from 1.21 births per woman in 2004 to 1.53 in 2012. It remains to be seen whether there will also be an effect on cohort fertility. The recuperation rates for young cohorts born in 1975 and 1980 (Table 3 and Fig. 4) indicate there might not be a further decline in cohort TFRs; however any increase compared to the 1970 birth cohort, when the CTFR(40) was 1.56 births per woman, is also unlikely.

Preschool childcare in public institutions has also been increasing steadily. In 2013, 62 percent of children attended crèches and kindergartens up from 41 percent in 2001.

An observation generally shared by Ukrainian professionals was formulated by Perelli-Harris (2008) who states that "Ukraine has one of the most generous but least effective family policies in the world." An important circumstance for the low impact of family policies appears to be the emphasis on material incentives, insufficient attention to work and family initiatives, and broad social change supportive of children and parenting. Moreover, the economic collapse and the grave conditions caused by internal strife and the Russian intervention are also being felt in the area of social and family policies. 


\section{Summaries and conclusions}

Meaningful observations and conclusions can be drawn from the above analysis of fertility trends and family policies in CEE.

\subsection{Fertility trends}

- In the majority of CEE countries births that were postponed by women born during the 1970s were not being replaced in sufficient numbers for cohort fertility to increase in the foreseeable future. A further decline is likely, stagnation is possible.

- Shares of low parity women (childless and one child) have become considerably larger than shares of high parity women with three or more children among the 1960s birth cohorts and there is no reason to believe this trend might be reversed.

- Shares of two-child families gradually declined, shares of one-child families increased and there were few childless women among the 1960s birth cohorts.

- Cohort childbearing age patterns in all CEE countries have been changing dramatically starting with the mid-1960s birth cohorts. These changes are continuing albeit at a more moderate pace among the 1970s and early 1980s cohorts.

- The slowdown in childbearing postponement indicates the possibility of cohort fertility stagnation.

Overall, cohort fertility in the majority of CEE countries is likely to decline among the 1970s birth cohorts. There might be some exceptions and stagnation is possible. The outlook for a fertility increase in the long run is not favourable. This constitutes a topic of serious concern for governments in the region and as such is among the reasons that motivate them to devise and implement family and other policies to counteract this development.

\subsection{Family policies: Discussion and conclusions}

Fertility levels and trends are indeed a matter of serious concern throughout the CEE region. Often the concern with inadequate fertility levels is within a broader framework of concern for the wellbeing of families and children, or with the objective of alleviation of poverty. Governments tend to adopt official programme documents outlining strategies how to deal with these issues. Sometimes institutions such as ministries, and committees, have been established to design and implement family policies. In some countries governments are pursuing at least a partial implementation of the enunciated policies. In others the proposed policies were not implemented and the intentions have remained unfulfilled due to political instability, ideological disagreements, lack of resources, or competing government priorities.

Issues related to child benefits, parental leaves and child care have been discussed above in the context of individual countries in section 5.3 (Country fam- 
ily policy profiles). In addition, appendix tables 9, 10 and 11 provide overviews of parental leaves, and of participation rates in child care for 0-2 and for 3-5 year old children.

The formulation and implementation of worthy family policies is subject to numerous challenges. Quite frequently parties alternating in power have different views on what should constitute a family policy. One party advances measures tainted by patriarchal attitudes with an emphasis on financial support to enable women to stay at home while the man provides for the family. Other political parties in principle promote family policies associated with gender equality, work-life balance, convenient employment conditions for women, and adequate institutional childcare. As parties alternate in power governments change policy measures adopted by previous administrations thus creating an atmosphere of uncertainty. Such situations were typical in Hungary and Lithuania, although other countries also suffered from this syndrome. In Poland the government did not declare an official government policy, but since 2008 gradually implemented some measures easing tensions between being employed and family care obligations.

In a number of countries family policies have been of low priority for governments. In particular, in Romania, an unstable political environment with frequently changing administrations, combined with a poorly performing economy are among the reasons why the government neglected family policies.

Some countries suffer from a lack of resources available for family policies. Governments in Serbia and Croatia expressed great concern about low fertility and the wellbeing of families and children. Official documents were drafted and committees formed, but policies were not implemented. The economies were performing poorly in part as a consequence of the wars which followed the disintegration of former Yugoslavia. Apparently, sufficient resources were not available for family policies to be implemented.

Frequently political instability has affected family policies. This has been the case not only in Hungary, Lithuania and Poland where it was identified as an important feature shaping family policies, but also in Romania, Slovakia, and Ukraine, and possibly to some extent elsewhere.

Although conclusive findings regarding the effect of family policies on fertility trends can only be made with a certain lapse of time, preliminary findings are emerging. In countries with recent prominent pro-natalist policies - Belarus, the Russian Federation, and Ukraine - period TFRs have increased more than in most other countries. In Bulgaria and Latvia, however, even the period TFR trend stalled around 2010. Looking ahead, if the pre-1990 experiences are an indication of what is transpiring, the period fertility increases might turn out to be temporary, caused largely by the advancement of childbearing from future years as usually happened in the past. In this case a cohort fertility steadying at a relatively low level or a decline is likely to continue.

In countries with the male breadwinner models - the Czech Republic and Slovakia - any notable effect on preventing a cohort fertility decline has not been apparent so far. However, the family policies might well have had other beneficial effects, such as a more just income distribution or poverty alleviation. 
In almost all the remaining countries that for different reasons have weak family policies - Poland, Romania, Croatia and Serbia - even period TFRs have experienced only modest growth. Lithuania is the exception with a period TFR at 1.6 in 2012 which had been increasing since the mid-2000s and with a relatively stable and high estimated cohort fertility rate.

In sum, these findings indicate that there are merely two countries in which family policies may have created favourable conditions for cohort fertility to stabilize - Estonia and Slovenia. On the other extreme, there are at least five - Croatia, Hungary, Poland, Serbia and Romania - possibly nine populations, if the Czech Republic, Slovakia, Bulgaria and Latvia are included, in which family policies have not prevented a continued cohort fertility decline. In four populations, if Lithuania is added to those with strong pro-natalist policies - Belarus, Russia, and Ukraine -, some immediate effects of family policies on period fertility trends have been noted however when the respective cohort fertility data will become available, these increases may turn out to have been temporary.

\subsection{Overall observations and conclusions}

Our research yields two main findings.

1. Cohort fertility is not likely to increase in the foreseeable future - i.e. among the 1970s birth cohorts and possibly beyond - in almost all CEE countries; it is more likely to decline; there are some indications of a possible stagnation of cohort fertility levels.

2. The majority of extant family policies in CEE countries are facing a variety of challenges that impede them from helping to generate optimal family welfare and to provide conditions for cohort fertility to increase. There are only two countries in which family policies are apparently conducive for a considerable advancement of family wellbeing and may have a positive impact on cohort fertility trends: Estonia and Slovenia. In addition, in four or five countries, immediate effects of family policies on period fertility trends have been noted, however these may turn out to be temporary with a limited effect on cohort fertility.

\subsection{Why are these findings important?}

Period fertility rates have been increasing in the late 2000 s and in some countries up until the early 2010 s. This has created the impression of a fertility recovery. Findings of this project indicate that no such widespread recovery of childbearing appears to be underway. Even though it cannot be proven conclusively at the present time, cohort fertility does not appear to be increasing. In addition, what exactly will happen with period fertility trends depends on trends in childbearing timing. The rise in period fertility rates might have been temporary if it turns out that the PTFR increases of the late 2000 s and early 2010 s were driven by a slowing down of childbearing postponement or by childbearing advancement. In this case a stagnation or period fertility decline can be expected in the mid to late 2010s. However, as there are some signs that childbearing postponement is merely slowing down, period 
fertility stagnation or decline might not occur soon, but in a number of years. Also, periodic increases in material incentives to childbearing, provided governments can afford to do so, might manage to maintain relatively high period fertility rates for a few years.

The likely future decline of cohort fertility (or its stagnation at relatively low levels) may entail long-term demographic as well as other societal consequences, such as continuous declines in total population numbers, changes in age structures, as well as implications for health and social security costs.

This is the first time that a relatively comprehensive analysis of the nature and performance of family policies in CEE countries after the collapse of state socialism has been performed. We hope that this study will provide governments with a realistic overview of existing policies, and what more can be done to tackle the abovementioned issues.

Recent research on differences between actual family size and the number of children women desire - or consider ideal - provides evidence that fertility could increase if appropriate conditions were generated. This would require improved general societal conditions for childbearing as well as effective comprehensive family policies. Sobotka and Beaujouan (2014: 407) have documented that "a two-child ideal has become nearly universal among women in Europe." Taking the data for eight CEE countries in their paper and for five additional ones there is a difference of 0.49 children per woman between the completed cohort fertility rate (1.64) and the mean ideal family size (2.13). If conditions for childbearing were to improve, women and couples might have a realistic opportunity to come closer to their ideal family size.

\section{References}

Adema, Willem et al. 2009: The OECD Family Data Database: Developing a crossnational tool for assessing family policies and outcomes. In: Child Indicators Research 2,4: 437-460.

Albanese, Patrizia 2006: Mothers of the Nation: Women, Families, and Nationalism in Twentieth-Century Europe. Toronto: University of Toronto Press Inc.

Basten, Stuart; Frejka, Tomas 2015: Fertility and Family Policies in Central and Eastern Europe. Barnett Papers in Social Research 15-01, Department of Social Policy and Intervention: University of Oxford.

Berelson, Bernard (Ed.) 1974: Population Policy in Developed Countries. New York: McGraw-Hill.

Besemeres, John F. 1980: Socialist Population Politics: The Political Implications of Demographic Trends in the USSR and Eastern Europe. Armonk, NY: Sharpe.

Billingsley, Sunnee 2010: The Post-communist Fertility Puzzle. In: Population Research and Policy Review 29,2: 193-231 [doi: 10.1007/s11113-009-9136-7].

Bongaarts, John 1978: A Framework for Analyzing the Proximate Determinants of Fertility. In: Population and Development Review 4,1: 105-132. 
Council of Europe 2006: Recent Demographic Developments in Europe. Strasbourg: Council of Europe Publishing.

David, Henry P. (Ed.) 1999: From Abortion to Contraception: A Resource to Public Policies and Reproductive Behaviour in Central and Eastern Europe from 1917 to Present. Westport, Connecticut: Greenwood Press.

David, Henry P.; Mclntyre, Robert J. 1981: Reproductive Behavior: Central and Eastern European Experience. New York: Springer Publishing Company

Davis, Kingsley; Blake, Judith 1956: Social Structure and Fertility: An Analytic Framework. In: Economic Development and Cultural Change 4: 211-235.

EBRD (European Bank for Reconstruction and Development) 2015: Transition Report 2013 [www.tr.ebrd.com, 15.03.2015].

Ekiert, Grzegorz; Hanson, Stephen E. (Eds.) 2003: Capitalism and Democracy in Central and Eastern Europe. Cambridge: Cambridge University Press.

Ekiert, Grzegorz; Kubik, Jan; Vachudova, Milada Anna 2007: Democracy in the PostCommunist World: An Unending Quest? In: East European Politics and Society 21,1:730 [doi: 10.1177/0888325406297170].

Esping-Andersen, Gøsta 1990: The Three Worlds of Welfare Capitalism. Cambridge: Polity Press.

Eurostat 2015: Statistical base [http://epp.eurostat.ec.europa.eu/portal/page/portal/statistics/themes, 15.03.2015].

Freedom House 2015: Freedom in the World 2015. Washington, D.C.

Frejka, Tomas 2008: Determinants of Family Formation and Childbearing during the Societal Transition in Central and Eastern Europe. In: Demographic Research 19,7: 139170 [doi: 10.4054/DemRes.2008.19.7].

Frejka, Tomas et al. [Eds.] 2008: Childbearing Trends and Policies in Europe. In: Demographic Research, Special Collection 7,19: 1-1178.

Frejka, Tomas; Zakharov, Sergei 2013: The Apparent Failure of Russia's Pronatalist Family Policies. In: Population and Development Review 39,4: 635-647 [doi: 10.1111/j.17284457.2013.00631.x]

Ilišin, Vlasta et al. 2013: Youths in Times of Crisis, First research of IDIZ-a i Zaklada Friedrich Ebert of the youths, Zagreb: Institute for Social Research in Zagreb and Friedrich Ebert Stiftung (in Croatian).

Gauthier, Anne H. 2002: Family Policies in Industrialized Countries: Is There Convergence? In: Population-E 57,2: 447-474.

HFD (Human Fertility Database), Max Planck Institute for Demographic Research (Germany) and Vienna Institute of Demography (Austria): [www.humanfertility.org, 201415].

Kohler, Hans-Peter; Billari, Francesco C.; Ortega, José Antonio 2002: The Emergence of Lowest-low Fertility in Europe during the 1990s. In: Population and Development Review 28,4: 641-680 [10.1111/j.1728-4457.2002.00641.x].

Kotowska, Irena; Jóźwiak, Janina [Eds.] 2003: Population of Central and Eastern Europe. Challenges and Opportunities. Warsaw: Statistical Publishing Establishment.

Macura, Milos/av 2000: Fertility Decline in the Transition Economies, 1989-1998: Economic and social factors revisited. In: Economic Survey of Europe 2000,1: 189-205. New York/Geneva: Economic Commission for Europe, United Nations. 
McDonald, Peter 2002: Sustaining Fertility through Public Policy: The Range of Options. In: Population-E. 57,3: 417-446.

Myrdal, Alva; Myrdal, Gunnar 1934: Kris i Befolkinsfrägen (Crisis in the Population Question).

Myrskylä, Mikko; Goldstein, Joshua R.; Cheng, Yen-hsin Alice 2013: New Cohort Fertility Forecasts for the Developed World. In: Population and Development Review 39,1: 31-56 [doi: 10.1111/j.1728-4457.2013.00572.x].

Nemtsov, Boris; Milov, Vladimir 2008: Независимый экспертный доклад «Путин. Итоги" (A Report of Independent Experts "Putin's achievements")

Neyer, Gerda 2003: Family Policies and Low Fertility in Western Europe. MPIDR Working Paper. WP 2003-021 [http://www.demogr.mpg.de/papers/working/wp-2003-021. pdf, 02.05.2016].

Observatoire Démographique Européen (ODE) 2012: No longer in existence.

OECD Family Policy Database 2016: [http://www.oecd.org/els/family/database.htm, 20.04.2015]

Perelli-Harris, Brienna 2008: Ukraine: On the Border between Old and New in Uncertain Times. In: Demographic Research 19,29: 1145-1178.

Rahn, Richard 2007: From Communism to Putinism. In: The Washington Times, 19 September 2007.

Rybakovsky, Leonid L. 2012 Demograficheskiye vyzovi: Chto ozhidayet Rossiyu? (Demographic Challenges: What can Russia Expect?), Sotsiologicheskiye Issledovaniya 2012,8: 49-60. [http://www.isras.ru/files/File/Socis/2012_8/Rybakovskiy.pdf, 25.05.2012].

Sedgh, Gilda et al. 2007: Legal Abortion Worldwide Incidence and Trends. In: International Family Planning Perspectives 33,3:106-116.

Sobotka, Tomáš 2004: Postponement of Childbearing and Low Fertility in Europe. \{PhD Thesis\}. University of Groningen. Amsterdam: Dutch University Press.

Sobotka, Tomáš 2011: Fertility in Central and Eastern Europe after 1989. Collapse and Gradual Recovery. In: Historical Social Research (Special issue Fertility in the 20th Century: trends, policies, theories, discourses) 36,2: 246-296.

Sobotka, Tomáš; Skirbekk, Vegard; Philipov, Dimiter 2011: Economic Recession and Fertility in the Developed World. In: Population and Development Review 37,2: 267-306 [doi: 10.1111/j.1728-4457.2011.00411.x].

Sobotka, Tomáš et al. 2011: Postponement and Recuperation in Cohort Fertility: Austria, Germany and Switzerland in a European Context. In: Comparative Population Studies - Zeitschrift für Bevölkerungswissenschaft 36,2-3: 417-452 [doi: 10.4232/10. CPoS-2011-10en].

Sobotka, Tomáš; Beaujouan, Éva 2014: Two Is Best? The Persistence of a Two-Child Family Ideal in Europe. In: Population and Development Review 40,3: 391-419 [doi: 10.1111/j.1728-4457.2014.00691.x].

Spéder, Zsolt; Kamarás, Ferenc 2008: Hungary: Secular fertility Decline with Distinct Period Fluctuations. In: Demographic Research 19,18: 599-664 [doi: 10.4054/DemRes.2008.19.18].

Stock, Günter et al. [Eds.] 2013: Zukunft mit Kindern - Fertilität und Gesellschaftliche Entwicklung in Deutschland, Österreich und der Schweiz [A Future with Children: Fertility and Development of Society in Germany, Austria, and Switzerland]. Frankfurt/ New York: Campus Verlag. 
Stropnik, Nada; Šircelj, Milivoja 2008: Slovenia: Generous Family Policy without Evidence of any Fertility Impact. In: Demographic Research 19,26: 1019-1058 [doi: 10.4054/DemRes.2008.19.26].

Thévenon, Olivier 2011: Family Policies in OECD Countries: A Comparative Analysis. In: Population and Development Review 37,1: 57-87 [doi: 10.1111/j.17284457.2011.00390.x].

Toulemon, Laurent; Pailhé, Ariane; Rossier, Clémentine 2008: France: High and Stable Fertility. In: Demographic Research 19,16: 503-555 [doi: 10.4054/DemRes.2008.19.16].

United Nations, Department of Economic and Social Affairs, Population Division 2006: Levels and Trends of Contraceptive Use as Assessed in 2002. ST/ESA/SER.A/239.

United Nations, Department of Economic and Social Affairs, Population Division 2015: Trends in Contraceptive Use Worldwide 2015. ST/ESA/SER.A/349.

World Bank 2015: International Comparison Program Database, 2015.

Zakharov, Sergei 1999: Fertility, Nuptiality, and Family Planning in Russia: Problems and Prospects. In: Demko, George J.; loffe, Grigory; Zaionchkovskaya, Zhanna [Eds.]: Population under Duress: the Geodemography of post-Soviet Russia. Boulder-Oxford: Westview Press: 41-58.

Dr. Tomas Frejka $(\varangle)$. Independent Consultant and Department of Social Policy and Intervention, University of Oxford. Oxford, United Kingdom. E-mail: tfrejka@aol.com URL: https://www.spi.ox.ac.uk/people/profile/frejka.html

Dr. Stuart Gietel-Basten. Department of Social Policy and Intervention, University of Oxford. Oxford, United Kingdom. E-mail: stuart.basten@spi.ox.ac.uk URL: https://www.spi.ox.ac.uk/people/profile/basten.html 


\section{Appendix}

Participating countries and collaborators working on project: Prospects for a fertility increase in the formerly socialist countries of Central and Eastern Europe

\begin{tabular}{ll}
\hline Country & Collaborators \\
\hline Belarus & Ekaterina Antipova, Tatyana Pronko, Liudmila Fakeyeva \\
Bulgaria & Elena von der Lippe, Dora Kostova \\
Croatia & Ivan Cipin, Anđelko Akrap, Marin Strmota \\
Czech Republic & Tomáš Sobotka, Kryštof Zeman, Anna Štastná \\
Estonia & Luule Sakkeus, Allan Puur, Martin Klesment, Liili Abuladze \\
Hungary & Julia Mikolai \\
Latvia & Peter Zvidrins, Liga Abolina \\
Lithuania & Vlada Stankuniene, Aiva Jasilioniene \\
Poland & Irena Kotowska, Krzysztof Tymicki, Anna Rybińska \\
Romania & Cornelia Muresan, lonut Foldes \\
Russian Federation & Anatoly Vishnevsky, Sergei Zakharov \\
Serbia & Mirjana Rasevic, Mirjana Bobic, Vasic Petar \\
Slovakia & Michaela Potančoková, Branislav Šprocha \\
Slovenia & Jože Sambt, Nada Stropnik \\
Ukraine & Iryna Kurylo, Svitlana Aksyonova, Boris Krimer \\
Project coordinators & Stuart Gietel-Basten, Tomas Frejka \\
\hline
\end{tabular}


Tab. A1: EBRD economic transition indicators index, Central and Eastern Europe, 1995, 2005 and 2012

\begin{tabular}{|c|c|c|c|}
\hline \multirow[t]{2}{*}{ Region, Country } & \multicolumn{3}{|c|}{$\begin{array}{l}\text { EBRD economic transition } \\
\text { indicators index }\end{array}$} \\
\hline & 1995 & 2005 & 2012 \\
\hline \multicolumn{4}{|l|}{ Central Europe } \\
\hline Croatia & 3.0 & 3.6 & 3.7 \\
\hline Czech Republic & \multicolumn{3}{|c|}{ EBRD Donor country as of 2006} \\
\hline Hungary & 3.7 & 4.0 & 4.1 \\
\hline Poland & 3.4 & 3.9 & 4.0 \\
\hline Slovakia & 3.5 & 4.0 & 4.1 \\
\hline Slovenia & 3.2 & 3.6 & 3.6 \\
\hline \multicolumn{4}{|c|}{ South-Eastern Europe } \\
\hline Albania & 2.8 & 3.3 & 3.5 \\
\hline Bulgaria & 2.6 & 3.6 & 3.7 \\
\hline Montenegro & 1.6 & 2.9 & 3.3 \\
\hline Serbia & 1.6 & 2.8 & 3.2 \\
\hline Romania & 2.6 & 3.4 & 3.7 \\
\hline \multicolumn{4}{|l|}{ Eastern Europe } \\
\hline Belarus & 2.2 & 1.9 & 2.2 \\
\hline Moldova & 2.9 & 3.2 & 3.3 \\
\hline Russia & 2.9 & 3.2 & 3.3 \\
\hline Ukraine & 2.4 & 3.2 & 3.3 \\
\hline \multicolumn{4}{|l|}{ Baltic States } \\
\hline Estonia & 3.6 & 4.0 & 4.1 \\
\hline Latvia & 3.1 & 3.8 & 3.9 \\
\hline Lithuania & 3.2 & 3.9 & 3.9 \\
\hline
\end{tabular}

Note: The measurement scale for the indicators ranges from 1 to $4+$, where 1 represents little or no change from a rigid centrally planned economy and 4+ represents the standards of an industrialized market economy.

Source: EBRD 2015 
Tab. A2: Political rights index and civil liberties index, Central and Eastern Europe, 2004 and 2014

\begin{tabular}{|c|c|c|c|c|c|c|}
\hline \multirow[t]{2}{*}{ Region, Country } & \multicolumn{3}{|c|}{2004} & \multicolumn{3}{|c|}{2014} \\
\hline & PR & $\mathrm{CL}$ & Status & PR & $\mathrm{CL}$ & Status \\
\hline \multicolumn{7}{|l|}{ Central Europe } \\
\hline Croatia & 2 & 2 & $\mathrm{~F}$ & 1 & 2 & $\mathrm{~F}$ \\
\hline Czech Republic & 1 & 1 & $\mathrm{~F}$ & 1 & 1 & $\mathrm{~F}$ \\
\hline Hungary & 1 & 1 & $\mathrm{~F}$ & 2 & 2 & $\mathrm{~F}$ \\
\hline Poland & 1 & 1 & $\mathrm{~F}$ & 1 & 1 & $\mathrm{~F}$ \\
\hline Slovakia & 1 & 1 & $\mathrm{~F}$ & 1 & 1 & $\mathrm{~F}$ \\
\hline Slovenia & 1 & 1 & $\mathrm{~F}$ & 1 & 1 & $\mathrm{~F}$ \\
\hline \multicolumn{7}{|c|}{ South-Eastern Europe } \\
\hline Albania & 3 & 3 & PF & 3 & 3 & PF \\
\hline Bulgaria & 1 & 2 & $\mathrm{~F}$ & 2 & 2 & $\mathrm{~F}$ \\
\hline Montenegro &.. &.. & .. & 3 & 2 & $\mathrm{~F}$ \\
\hline Serbia & .. &.. & .. & 2 & 2 & $\mathrm{~F}$ \\
\hline Romania & 3 & 2 & $\mathrm{~F}$ & 2 & 2 & $\mathrm{~F}$ \\
\hline \multicolumn{7}{|l|}{ Eastern Europe } \\
\hline Belarus & 7 & 6 & NF & 7 & 6 & NF \\
\hline Moldova & 3 & 4 & PF & 3 & 3 & PF \\
\hline Russia & 6 & 5 & NF & 6 & 6 & NF \\
\hline Ukraine & 4 & 3 & PF & 3 & 3 & PF \\
\hline \multicolumn{7}{|l|}{ Baltic States } \\
\hline Estonia & 1 & 1 & $\mathrm{~F}$ & 1 & 1 & $\mathrm{~F}$ \\
\hline Latvia & 1 & 2 & $\mathrm{~F}$ & 2 & 2 & $\mathrm{~F}$ \\
\hline Lithuania & 2 & 2 & $\mathrm{~F}$ & 1 & 1 & $\mathrm{~F}$ \\
\hline
\end{tabular}

Notes: PR - Political rights; CL - Civil liberties; F - Free; PF - Partially free; NF - Not free Numerical ratings from 1 to $7-1$ representing the most free and 7 the least free

Source: Freedom House 2015 
Tab. A3: Annual gross domestic product per capita based on purchasing power parity, Central and Eastern Europe, and selected Western European countries, 1990-2013

\begin{tabular}{|c|c|c|c|c|c|c|}
\hline \multirow[t]{2}{*}{ Region, Country } & \multicolumn{3}{|c|}{$\begin{array}{c}\text { GDP per capita based on } \\
\text { PPP in \$\$ }\end{array}$} & \multicolumn{2}{|c|}{$\begin{array}{l}\text { Average annual growth } \\
\text { rate of GDP per capita } \\
\text { based on PPP in percent }\end{array}$} & \multirow[t]{2}{*}{$\begin{array}{c}\text { GDP per capita } \\
\text { based on PPP } \\
2013 / 1990\end{array}$} \\
\hline & 1990 & 2000 & 2013 & $2000 / 1990$ & $2013 / 2000$ & \\
\hline \multicolumn{7}{|l|}{ Central Europe } \\
\hline Croatia & n.a. & 11,057 & 21,351 & n.a. & 5.1 & n.a. \\
\hline Czech Republic & 12,731 & 16,287 & 29,018 & 2.5 & 4.4 & 2.28 \\
\hline Hungary & $8,257^{a}$ & 12,073 & 23,334 & 4.2 & 5.1 & 2.83 \\
\hline Poland & 6,003 & 10,600 & 23,690 & 5.7 & 6.2 & 3.95 \\
\hline Slovakia & $6,997^{b}$ & 11,160 & 26,497 & 5.8 & 6.7 & 3.79 \\
\hline Slovenia & n.a. & 17,882 & 28,859 & n.a. & 3.7 & n.a. \\
\hline \multicolumn{7}{|c|}{ South-Eastern Europe } \\
\hline Albania & 2,844 & 4,249 & 9,931 & 4.0 & 6.5 & 3.49 \\
\hline Bulgaria & 5,410 & 6,445 & 15,732 & 1.8 & 6.9 & 2.91 \\
\hline Montenegro & n.a. & 6,548 & 14,132 & n.a. & 5.9 & n.a. \\
\hline Serbia & n.a. & 5,778 & 13,020 & n.a. & 6.2 & n.a. \\
\hline Romania & 5,193 & 5,707 & 18,974 & 0.9 & 9.2 & 3.65 \\
\hline \multicolumn{7}{|l|}{ Eastern Europe } \\
\hline Belarus & 5,230 & 5,786 & 17,620 & 1.0 & 8.6 & 3.37 \\
\hline Moldova & 4,153 & 1,840 & 4,671 & -8.1 & 7.2 & 1.12 \\
\hline Russia & 8,014 & 6,825 & 25,248 & -1.6 & 10.1 & 3.15 \\
\hline Ukraine & 6,798 & 3,818 & 8,790 & -5.8 & 6.4 & 1.29 \\
\hline \multicolumn{7}{|l|}{ Baltic States } \\
\hline Estonia & n.a. & 9,709 & 25,823 & n.a. & 7.5 & n.a. \\
\hline Latvia & 7,829 & 8,061 & 22,568 & 0.3 & 7.9 & 2.88 \\
\hline Lithuania & 9,324 & 8,619 & 25,454 & -0.8 & 8.3 & 2.73 \\
\hline \multicolumn{7}{|c|}{ Selected Western European countries } \\
\hline Norway & 17,914 & & 64,406 & & & 3.60 \\
\hline United States & 23,955 & & 53,042 & & & 2.21 \\
\hline Netherlands & 18,740 & & 46,162 & & & 2.46 \\
\hline Austria & 19,514 & & 45,079 & & & 2.31 \\
\hline Portugal & 11,198 & & 27,804 & & & 2.48 \\
\hline
\end{tabular}

a 1991;

b 1992. GDP per capita based on purchasing power parity (PPP). GDP is gross domestic product converted to international dollars using purchasing power parity rates. An international dollar has the same purchasing power over GDP as the U.S. dollar has in the United States.

Source: World Bank, International Comparison Program Database 2015 
Tab. A4: Period total fertility rates, increase or decline of period age-specific fertility rates, ages 15-26 and ages $27-49$, specified periods in 2000 2012, Central and East European countries by region

\begin{tabular}{|c|c|c|c|c|c|c|}
\hline \multirow[t]{2}{*}{ Region, Country } & \multirow[t]{2}{*}{ Period } & \multicolumn{2}{|c|}{$\begin{array}{c}\text { Increase or decrease of } \\
\text { period age-specific fertility } \\
\text { rate (in percent) }\end{array}$} & \multirow[t]{2}{*}{$\begin{array}{l}\text { PTFR at end } \\
\text { of period }\end{array}$} & \multicolumn{2}{|c|}{$\begin{array}{l}\text { Share of period age- } \\
\text { specific fertility rate at end } \\
\text { of period (in percent) }\end{array}$} \\
\hline & & ages $15-26$ & ages 27-49 & & ages $15-26$ & ages 27-49 \\
\hline \multicolumn{7}{|l|}{ Central Europe } \\
\hline Croatia & n.a. & n.a. & n.a. & n.a. & n.a. & n.a. \\
\hline Czech Republic & 2004-2012 & -14 & 41 & 1.45 & 28 & 72 \\
\hline Hungary & 2003-2009 & -18 & 21 & 1.32 & 34 & 66 \\
\hline Poland & 2004-2011 & -13 & 19 & 1.29 & 37 & 63 \\
\hline Slovakia & 2003-2012 & -14 & 58 & 1.46 & 36 & 64 \\
\hline Slovenia & $2003-2010$ & -1 & 49 & 1.57 & 26 & 74 \\
\hline \multicolumn{7}{|c|}{ South-Eastern Europe } \\
\hline Bulgaria & 2003-2009 & 8 & 60 & 1.57 & 53 & 47 \\
\hline Romania & n.a. & n.a. & n.a. & n.a. & n.a. & n.a. \\
\hline Serbia & $2000-2012$ & -30 & 33 & 1.44 & 40 & 60 \\
\hline \multicolumn{7}{|l|}{ Baltic States } \\
\hline Estonia & $2003-2010$ & -11 & 47 & 1.63 & 36 & 64 \\
\hline Latvia & n.a. & n.a. & n.a. & n.a. & n.a. & n.a. \\
\hline Lithuania & $2002-2011$ & -19 & 82 & 1.55 & 36 & 64 \\
\hline \multicolumn{7}{|l|}{ Eastern Europe } \\
\hline Belarus & 2004-2012 & 7 & 70 & 1.62 & 50 & 50 \\
\hline Russia & 2006-2012 & 10 & 58 & 1.69 & 47 & 53 \\
\hline Ukraine & 2004-2012 & 3 & 66 & 1.53 & 52 & 48 \\
\hline
\end{tabular}

Source: Human Fertility Database 2014, Warsaw School of Economics 2014: Personal communication 
Tab. A5: Parity distributions, selected Central and East European countries, Birth cohorts 1960-1970

\begin{tabular}{|c|c|c|c|c|c|c|c|c|c|}
\hline \multirow[b]{2}{*}{ Cohort } & \multicolumn{3}{|c|}{$\begin{array}{l}\text { Parities share } \\
\text { (in percent) }\end{array}$} & \multirow{2}{*}{$\begin{array}{c}\text { Parities } \\
\text { Ratio } \\
0+1 / 3+\end{array}$} & \multirow[b]{2}{*}{ Cohort } & \multicolumn{3}{|c|}{$\begin{array}{l}\text { Parities share } \\
\text { (in percent) }\end{array}$} & \multirow{2}{*}{$\begin{array}{c}\text { Parities } \\
\text { Ratio } \\
0+1 / 3+\end{array}$} \\
\hline & $0+1$ & 2 & $3+$ & & & $0+1$ & 2 & $3+$ & \\
\hline Czech Republic & & & & & Hungary & & & & \\
\hline 1960 & 22 & 56 & 23 & 1.0 & 1960 & 27 & 49 & 23 & 1.2 \\
\hline 1965 & 26 & 55 & 19 & 1.3 & 1965 & 30 & 46 & 24 & 1.3 \\
\hline 1970 & 29 & 53 & 17 & 1.7 & 1968 & 34 & 42 & 23 & 1.5 \\
\hline Slovakia & & & & & Bulgaria & & & & \\
\hline 1960 & 23 & 45 & 32 & 0.7 & 1960 & 25 & 59 & 16 & 1.6 \\
\hline 1965 & 28 & 46 & 27 & 1.0 & 1965 & 33 & 54 & 13 & 2.5 \\
\hline 1968 & 31 & 45 & 25 & 1.3 & 1968 & 40 & 49 & 11 & 3.5 \\
\hline Estonia & & & & & Lithuania & & & & \\
\hline 1960 & 29 & 48 & 23 & 1.3 & 1960 & 33 & 49 & 18 & 1.9 \\
\hline 1965 & 37 & 42 & 21 & 1.7 & 1965 & 39 & 44 & 17 & 2.3 \\
\hline 1970 & 40 & 38 & 22 & 1.8 & 1970 & 40 & 43 & 17 & 2.4 \\
\hline Belarus & & & & & Russia & & & & \\
\hline 1960 & 30 & 56 & 14 & 2.1 & 1960 & 34 & 49 & 16 & 2.1 \\
\hline 1965 & 40 & 49 & 11 & 3.5 & 1965 & 44 & 43 & 13 & 3.3 \\
\hline 1970 & 45 & 44 & 11 & 4.1 & 1969 & 50 & 38 & 12 & 4.1 \\
\hline Ukraine & & & & & & & & & \\
\hline 1960 & 34 & 52 & 14 & 2.4 & & & & & \\
\hline 1965 & 43 & 46 & 11 & 3.8 & & & & & \\
\hline 1968 & 49 & 40 & 10 & 4.8 & & & & & \\
\hline
\end{tabular}

Note: All calculations performed with unrounded base data. Results may seem inaccurate when ratios are calculated with listed numbers, and totals of shares in rows for cohorts may not add exactly to 100 .

Source: Human Fertility Database 2014 
Fertility and Family Policies in Central and Eastern Europe after 1990

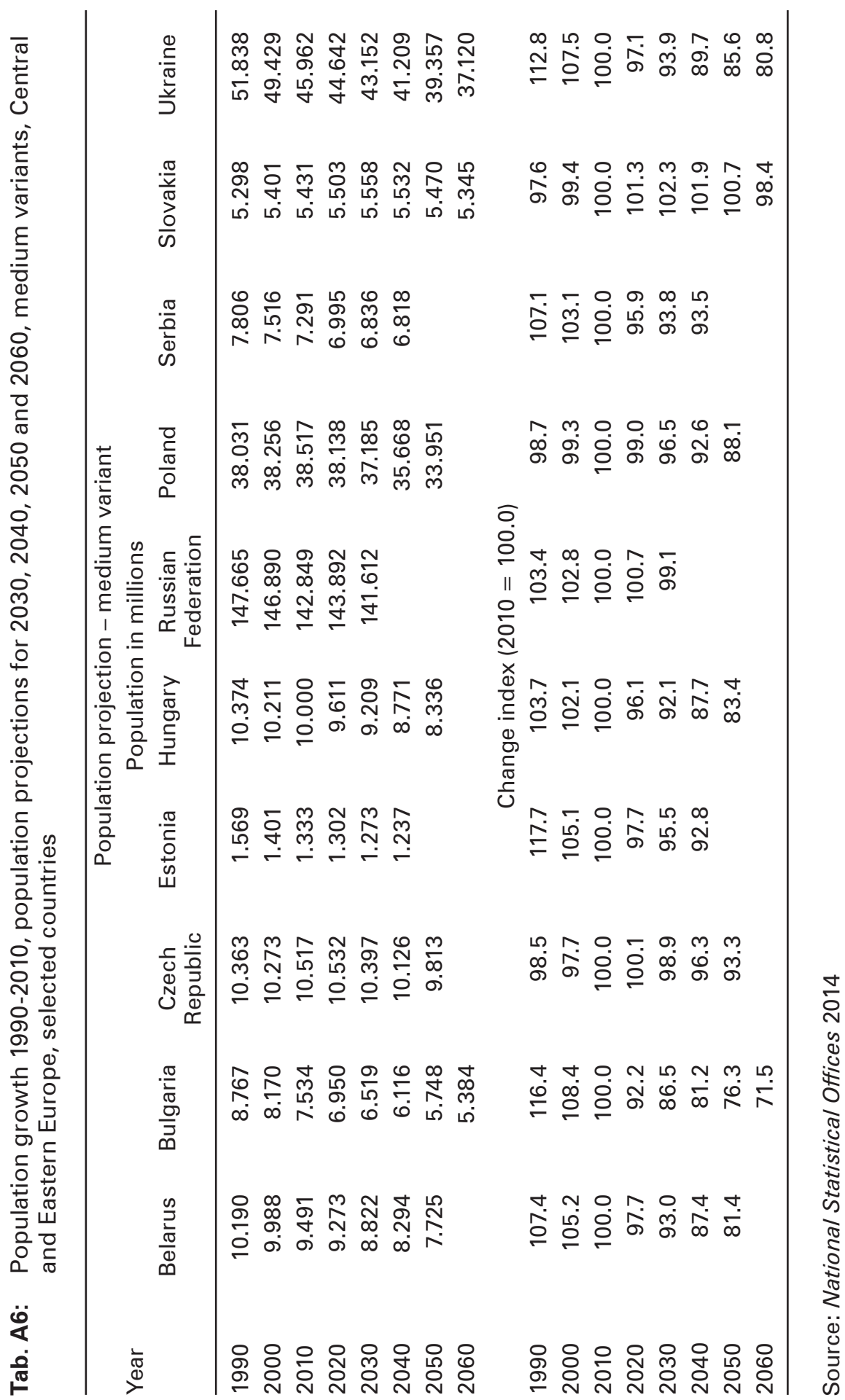


Tab.A7: Contraceptive prevalence, selected Central and East European countries, 1976-2015

\begin{tabular}{|c|c|c|c|c|}
\hline \multirow[t]{2}{*}{ Country } & \multirow[t]{2}{*}{ Year } & \multicolumn{3}{|c|}{ Contraceptive prevalence ${ }^{\mathrm{a}}$ (percentage) } \\
\hline & & Any method & Modern methods & Traditional methods \\
\hline \multirow[t]{5}{*}{ Bulgaria } & 1976 & 75.1 & 6.0 & 69.1 \\
\hline & 1994 & 80.1 & 45.6 & 34.4 \\
\hline & 1995 & 85.9 & 45.6 & 40.3 \\
\hline & 1997 & 41.5 & 25.6 & 15.9 \\
\hline & 2015 & 67.4 & 47.7 & 19.7 \\
\hline \multirow[t]{5}{*}{ Czech Republic } & 1977 & 95.0 & 49.0 & 46.0 \\
\hline & 1993 & 68.9 & 44.9 & 24.0 \\
\hline & 1994 & 69.6 & 48.6 & 21.0 \\
\hline & 1997 & 72.0 & 62.6 & 9.4 \\
\hline & 2015 & 74.8 & 69.1 & 8.7 \\
\hline \multirow[t]{2}{*}{ Hungary } & 1986 & 73.1 & 62.3 & 10.8 \\
\hline & 1992/1993 & 77.4 & 68.4 & 9.0 \\
\hline \multirow[t]{2}{*}{ Poland } & 1977 & 75.0 & 26.0 & 49.0 \\
\hline & 1991 & 49.4 & 19.0 & 30.4 \\
\hline \multirow[t]{5}{*}{ Romania } & 1978 & 58.0 & 5.0 & 53.0 \\
\hline & 1993 & 57.3 & 14.5 & 42.8 \\
\hline & 1994 & 60.5 & 16.3 & 44.3 \\
\hline & 1999 & 63.8 & 29.5 & 34.3 \\
\hline & 2015 & 69.0 & 53.7 & 34.3 \\
\hline Serbia \& & 1976 & 55.0 & 12.0 & 43.0 \\
\hline Montenegro & 2000 & 58.3 & 32.8 & 25.5 \\
\hline
\end{tabular}

a Percentage of women of reproductive age in a marital or consensual union using contraception

Source: United Nations 2002 and 2015 
Tab. A8: Legal abortions, selected Central and East European countries, 1996 and 2003

\begin{tabular}{lrcc}
\hline Country & \multicolumn{3}{c}{ Abortion rate $^{a}$} \\
& 1996 & 2003 & Average annual percent change \\
\hline Belarus & n.a. & 35 & n.a. \\
Bulgaria & 51 & 22 & -11.7 \\
Czech Republic & 21 & 13 & -6.9 \\
Hungary & 35 & 26 & -4.2 \\
Russian Federation & 69 & 45 & -6.0 \\
Slovak Republic & 20 & 13 & -6.1 \\
Estonia & 56 & 36 & -6.1 \\
Latvia & 44 & 29 & -6.0 \\
Lithuania & 34 & 15 & -11.0 \\
\hline
\end{tabular}

a Abortions per 1,000 women aged 15-44

Source: Sedgh et al. 2007 
Tab. A9: Paid leave entitlements: Full-rate equivalent paid maternity, parental and father-specific leave, in weeks, selected Central and East European countries, 2014

\begin{tabular}{lcccc}
\hline Country & $\begin{array}{c}\text { Paid maternity } \\
\text { leave }\end{array}$ & $\begin{array}{c}\text { Paid parental } \\
\text { and home care } \\
\text { leave available } \\
\text { to mothers }\end{array}$ & $\begin{array}{c}\text { Total paid leave } \\
\text { for mothers }\end{array}$ & $\begin{array}{c}\text { Paid leave } \\
\text { reserved for } \\
\text { fathers }\end{array}$ \\
\hline Belarus & 1 & 2 & $3=1+2$ & 4 \\
Ukraine & 23.0 & 144.0 & 167.0 & 0.0 \\
Slovak Republic & $10.0(18.0)$ & 156.0 & 166.0 & 0.0 \\
Estonia & 34.0 & 130.0 & 164.0 & 0.0 \\
Hungary & 20.0 & 140.3 & 160.3 & 2.0 \\
Bulgaria & 24.0 & 136.0 & 160.0 & 1.0 \\
Czech Republic & 58.6 & 51.9 & 110.4 & 2.1 \\
Latvia & 28.0 & 82.0 & 110.0 & 0.0 \\
Russian Federation & 16.0 & 78.0 & 94.0 & 1.4 \\
Lithuaniac & 20.0 & 68.2 & 82.2 & 0.0 \\
Romania & 18.0 & $44.0(96.0)$ & $62.0(114.0)$ & 4.0 \\
Croatia & 18.0 & 43.0 & 61.0 & 1.0 \\
Slovenia & 30.0 & 26.0 & 56.0 & 8.7 \\
Serbia & 15.0 & 37.1 & 52.1 & 2.1 \\
Poland & 16.0 & 36.0 & 52.0 & 0.0 \\
OECD average & 26.0 & 0.0 & 26.0 & 2.0 \\
\hline & 17.0 & 36.7 & 53.7 & 9.0 \\
\hline
\end{tabular}

a Entitled weeks of paid leave as of April 2014.

b In Ukraine the "Total paid leave for mothers" (col. 3=166 weeks) consists of 10 weeks of "Paid maternity leave" (col. 1) prior to birth plus 156 weeks of monthly payment of birth grant. The total paid maternity leave is 18 months as noted in parentheses in col. 1.

c In Lithuania parental leave is available not only for mothers but also for fathers, i.e. they are equally eligible to take it (not at the same time). Additionally, parents can choose between a 44-week parental leave with a benefit covering 100 percent of the compensatory wage and a 96-week parental leave with a benefit covering 70 percent of the compensatory wage in the first 44 weeks and 40 percent in the remaining 52 weeks (see also section 5.3.8).

d Parental leave and subsequent periods of paid home care leave to care for young children.

e Parental leave that can be used only by father and cannot be transferred to mother.

Source: OECD 2015, country co-author reports 
Tab. A10: Participation rates in childcare and pre-school services ${ }^{a}$ for $0-2$ year olds, selected Central and East European countries, 2006 and 2013

\begin{tabular}{lcc}
\hline Country & \multicolumn{2}{c}{ Participation rate (in percent) } \\
& 2006 & 2013 \\
\hline Slovenia & 32.5 & 45.4 \\
Estonia & 18.1 & 24.3 \\
Latvia & 20.0 & 23.4 \\
Russian Federation & 21.2 & 17.8 \\
Serbia & 11.3 & 16.2 \\
Hungary & 10.5 & 16.1 \\
Ukraine & 15.2 & 15.3 \\
Belarus & $11.9(2005)$ & $15.2(2012)$ \\
Romania & 7.9 & 14.5 \\
Bulgaria & 8.7 & 12.1 \\
Lithuania & 8.1 & 12.1 \\
Croatia & $\mathrm{n} . \mathrm{a}$. & 12.0 \\
Poland & 8.6 & 9.6 \\
Czech Republic & 2.6 & 4.3 \\
Slovak Republic & 4.9 & 3.1 \\
OECD 30 average & 28.1 & 32.9 \\
\hline
\end{tabular}

a Children in daycare centers and pre-school (private and public) and those that are cared for by licensed childminders

Source: OECD 2015, country co-author reports 
Tab. A11: Participation rates for 3-5 year olds in pre-primary education or primary school, a selected Central and East European countries, 2002 and 2012

\begin{tabular}{lcc}
\hline Country & \multicolumn{2}{c}{ Participation rate (in percent) } \\
& 2002 & 2012 \\
\hline Estonia & n.a. & 89.6 \\
Slovenia & n.a. & 88.8 \\
Hungary & 86.4 & 87.7 \\
Latvia & 64.3 & 87.7 \\
Belarus & $84.7(2005)$ & $83.9(2012)$ \\
Russian Federation & n.a. & 81.0 \\
Bulgaria & 73.1 & 79.6 \\
Ukraine & 58.0 & 78.4 \\
Romania & 61.9 & 77.6 \\
Czech Republic & 82.4 & 76.4 \\
Lithuania & 52.8 & 74.4 \\
Slovak Republic & 69.5 & 72.0 \\
Poland & 33.1 & 69.2 \\
Croatia & 41.5 & 57.7 \\
Serbia & 20.2 & 28.9 \\
OECD 29 average & 72.2 & 82.0 \\
\hline
\end{tabular}

a Children in pre-primary education (public and private), but also in some countries children in compulsory primary education

Source: OECD 2015, country co-author reports 
Fig. A1: Period total fertility rates, Central and Eastern Europe, Northern, Western, Southern Europe and German-speaking countries, 1970-2013

Period total fertility rate

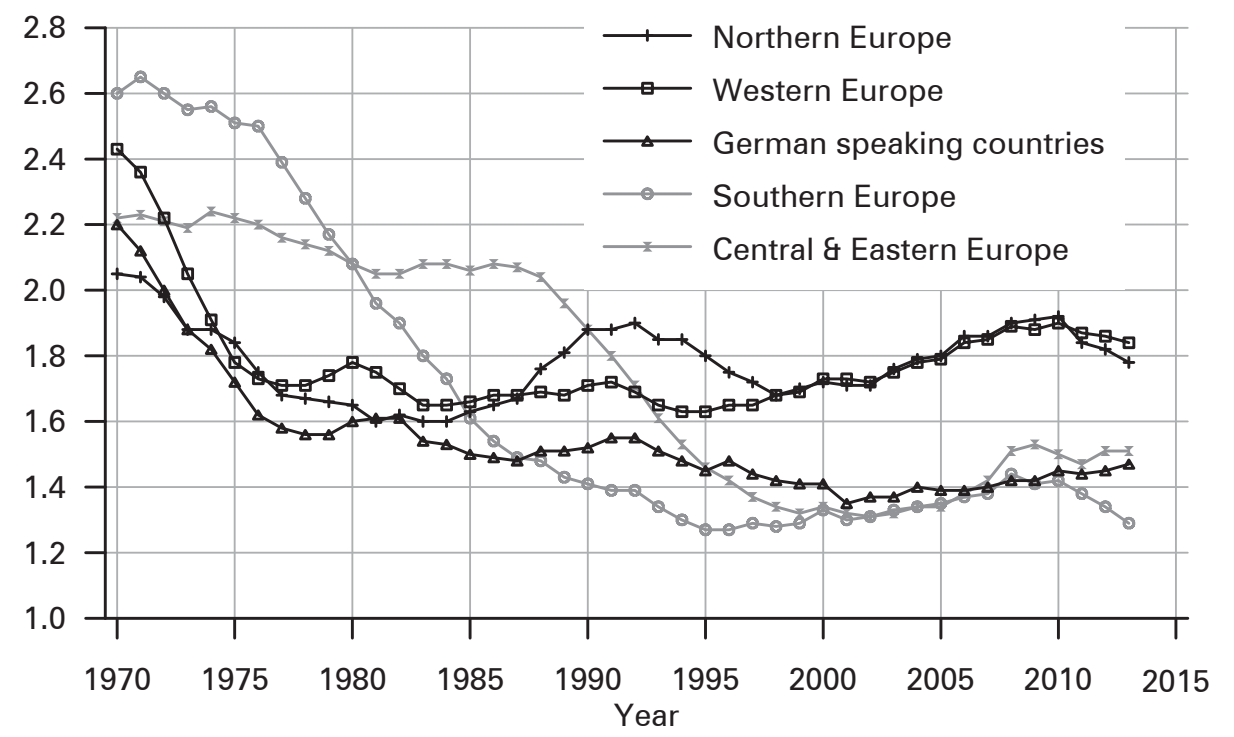

Regions consist of following countries

Central and Eastern Europe: Croatia, Czech Republic, Hungary, Poland, Slovakia, Slovenia, Albania, Bulgaria, Montenegro, Serbia, Romania, Belarus, Russian Federation, Ukraine, Estonia, Latvia, Lithuania

Northern Europe: Denmark, Finland, Norway, Sweden

Western Europe: Belgium, France, Netherlands, United Kingdom

German-speaking countries: Austria, Germany, Switzerland

Southern Europe: Greece, Italy, Portugal, Spain

Source: Human Fertility Database 2015 and Eurostat 2015 
Fig. A2: Mean age of mother at first birth, Central and Eastern Europe, Central, South-Eastern, Eastern Europe, and Baltic States, country populations within regions, 1960-2013

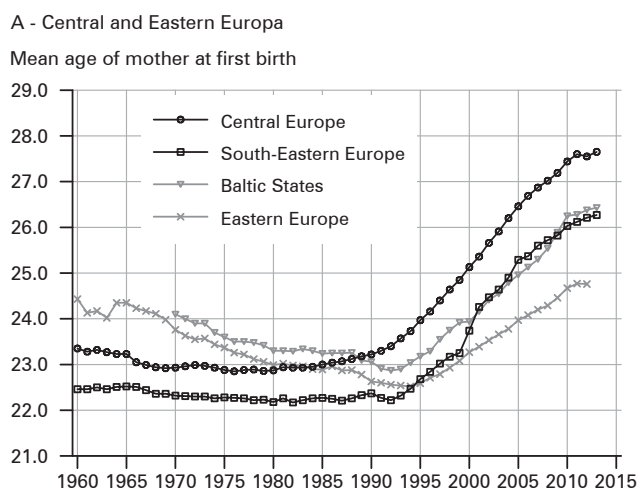

Year

C - South-Eastern Europe

Mean age of mother at first birth

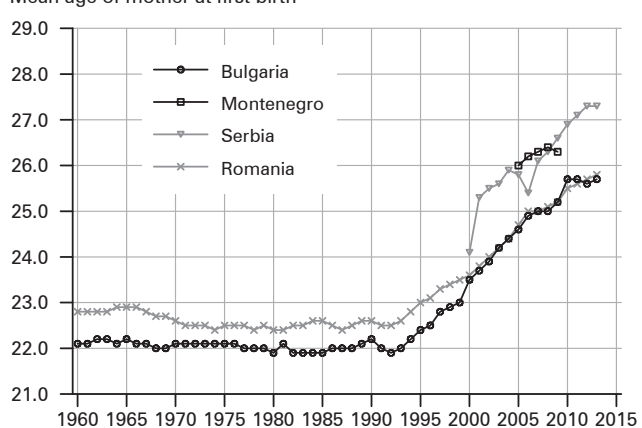

Year

E - Baltic States

Mean age of mother at first birth

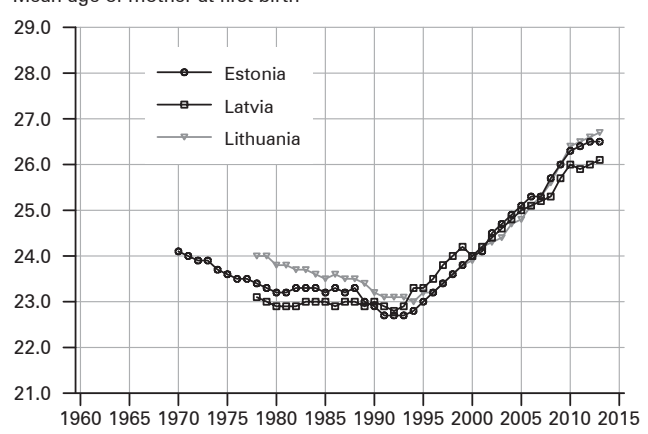

Year

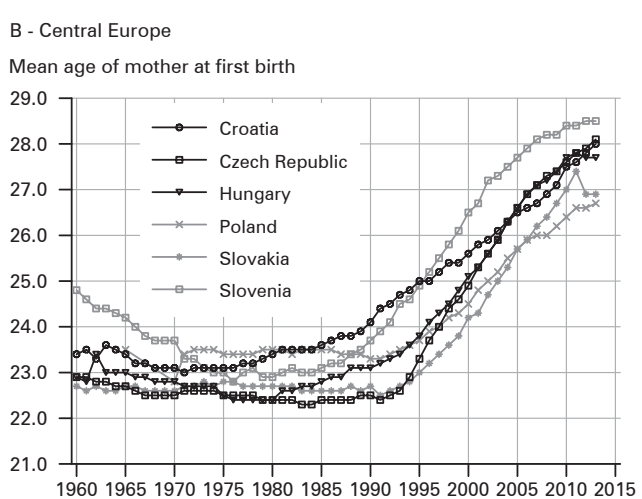

Year

D - Eastern Europe

Mean age of mother at first birth

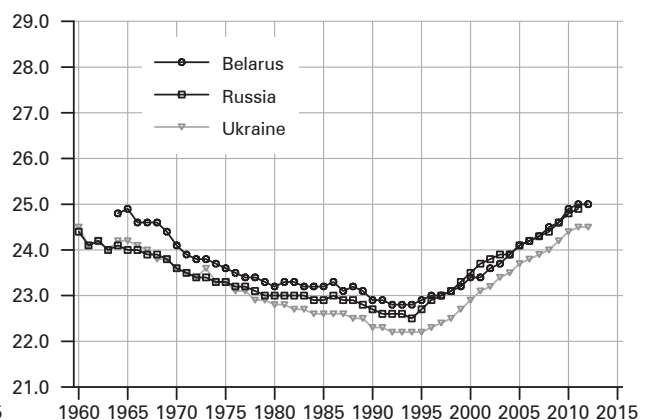

Year

Source: Human Fertility Database 2014, Eurostat 2015, Warsaw School of Economics 2014: Personal communication 
Fig. A3: Period total fertility rates (PTFR), period age-specific fertility rates of young women (PASFR 15-26), and period age-specific rates of older women (PASFR 27-49), selected Central and East European countries 1970-2014
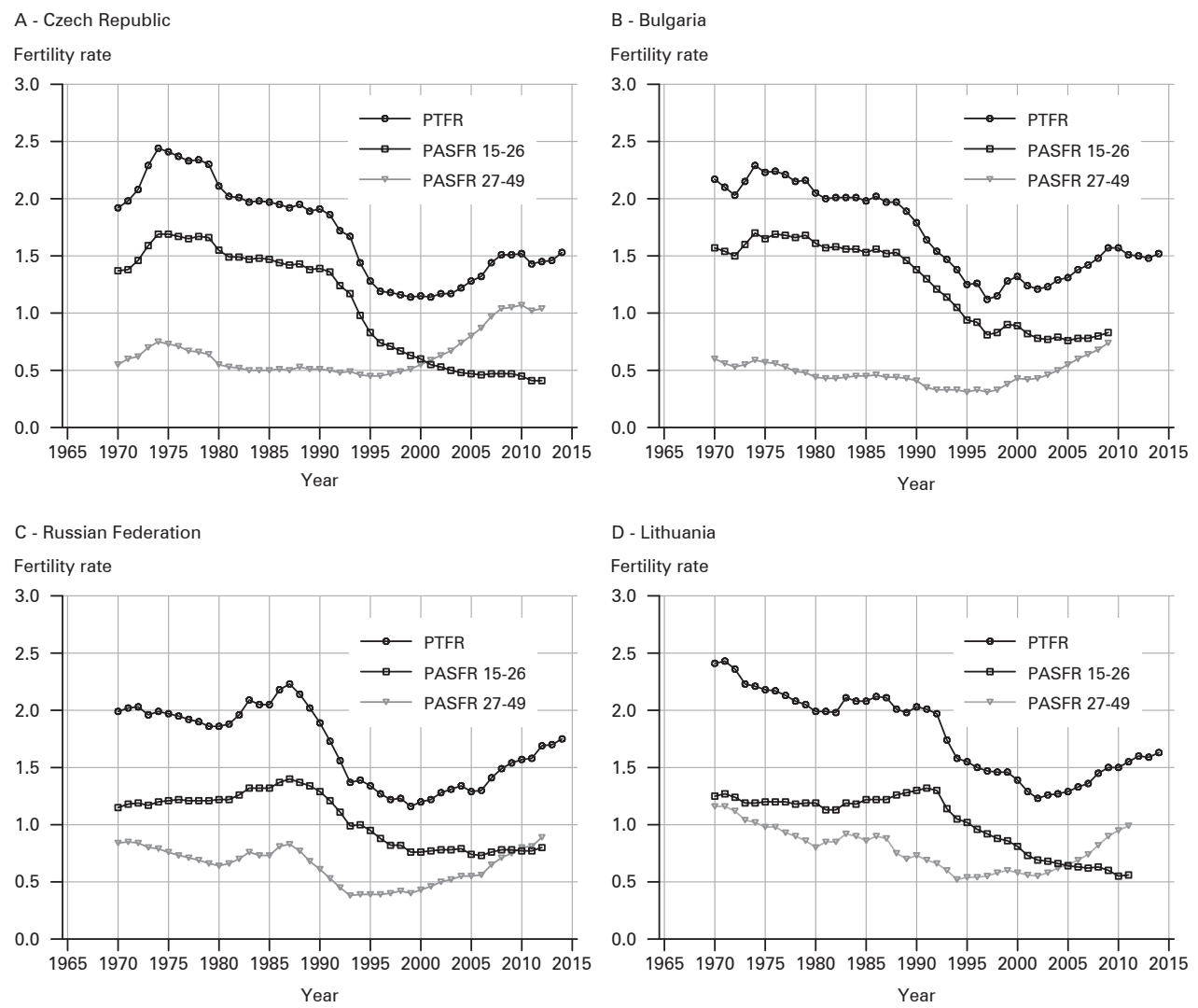

Source: Human Fertility Database 2015, Eurostat 2015, National statistical offices 2015 
Fig. A4: Cohort age-specific fertility rates, Czech Republic, Bulgaria, Russian Federation, Lithuania, and Austria, birth cohorts, 1965, 1970, 1975, 1980 and 1985, and Netherlands, birth cohorts, 1945, 1950, 1955, 1960 and 1965
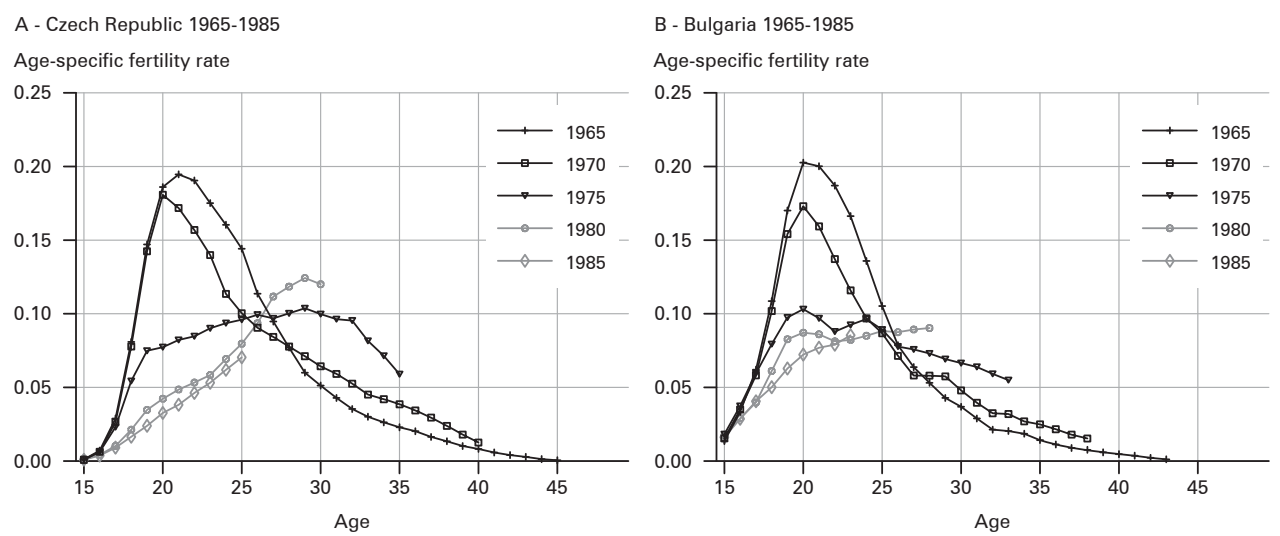

C - Russian Federation 1965-1985 D - Lithuania 1965-1985 Age-specific fertility rate

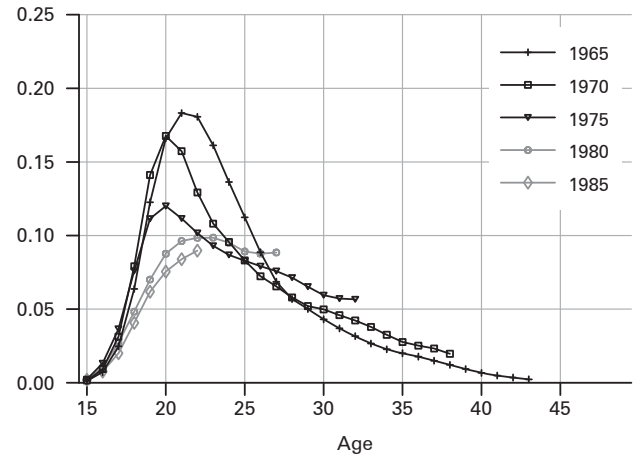
Age-specific fertility rate

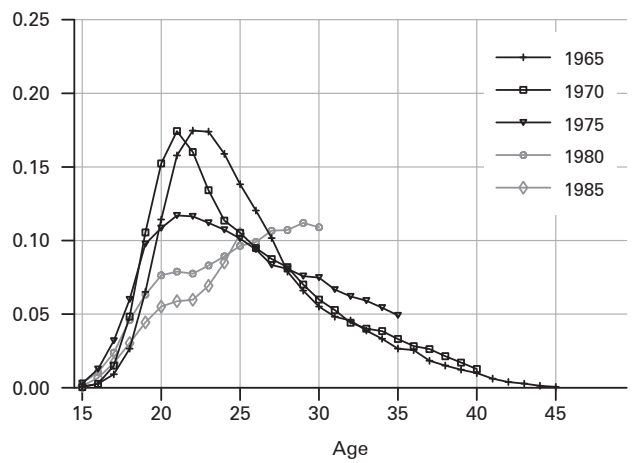

E - Netherlands 1965-1985

F - Austria 1965-1985

Age-specific fertility rate

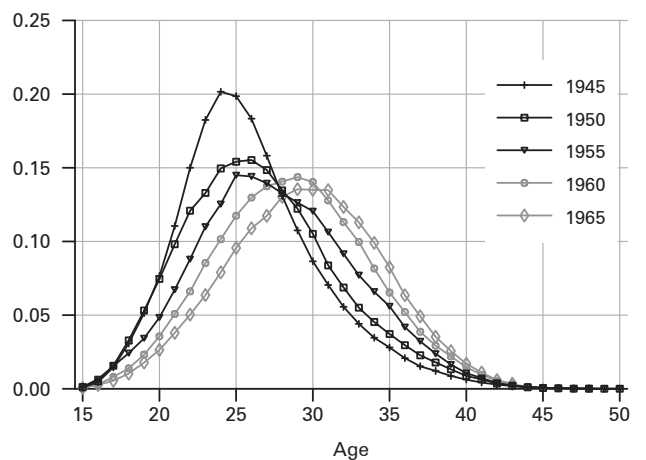

Age-specific fertility rate

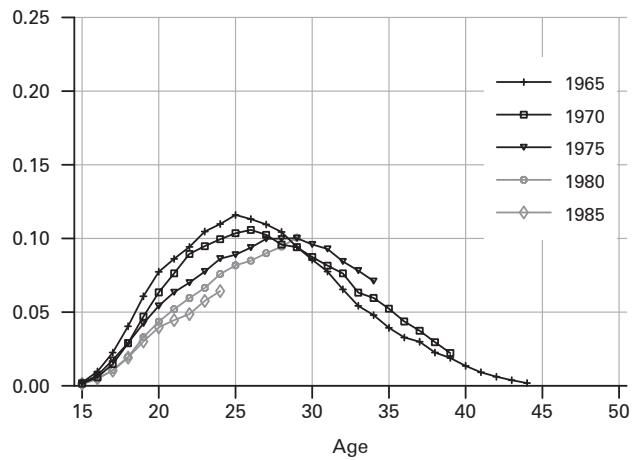

Source: Human Fertility Database 2015, Eurostat 2015, National statistical offices 2015 


\section{Comparative Population Studies}

WWW.comparativepopulationstudies.de

ISSN: 1869-8980 (Print) - 1869-8999 (Internet)

Published by

Prof. Dr. Norbert F. Schneider

Federal Institute for Population Research D-65180 Wiesbaden / Germany

\section{(cc) BY-SA}

2016

\section{Managing Editor}

Frank Swiaczny

\section{Assistant Managing Editor}

Katrin Schiefer

\section{Copy Editor}

(Selected Articles in German)

Dr. Evelyn Grünheid

\section{Layout}

Beatriz Feiler-Fuchs

E-mail:cpos@bib.bund.de

\section{Scientific Advisory Board}

Paul Gans (Mannheim)

Karsten Hank (Köln)

Johannes Huinink (Bremen)

Michaela Kreyenfeld (Rostock)

Marc Luy (Wien)

Notburga Ott (Bochum)

Peter Preisendörfer (Mainz)

Nikola Sander (Groningen)

Zsolt Spéder (Budapest)

\section{Board of Reviewers}

Martin Abraham (Erlangen)

Laura Bernardi (Lausanne)

Hansjörg Bucher (Bonn)

Claudia Diehl (Konstanz)

Andreas Diekmann (Zürich)

Gabriele Doblhammer-Reiter (Rostock)

Jürgen Dorbritz (Wiesbaden)

Anette Eva Fasang (Berlin)

E.-Jürgen Flöthmann (Bielefeld)

Alexia Fürnkranz-Prskawetz (Wien)

Beat Fux (Salzburg)

Joshua Goldstein (Berkeley)

Sonja Haug (Regensburg)

Hill Kulu (Liverpool)

Aart C. Liefbroer (Den Haag)

Kurt Lüscher (Konstanz)

Emma Lundholm (Umeå)

Nadja Milewski (Rostock)

Dimiter Philipov (Wien)

Roland Rau (Rostock)

Tomáš Sobotka (Wien) Jeroen Spijker (Barcelona)

Olivier Thévenon (Paris)

Helga de Valk (Brussel)

Heike Trappe (Rostock)

Michael Wagner (Köln) 